\title{
Chemistry of quartz related to the Zinnwald/Cínovec Sn-W-Li greisen-type deposit, Eastern Erzgebirge, Germany
}

Axel Müller ${ }^{1,2}$, Gunter Herklotz ${ }^{3}$, Horst Giegling ${ }^{3}$

${ }^{1}$ Natural History Museum, University of Oslo, P.O. Box 1172 Blindern, N-0318 Oslo, Norway, e-mail: a.b.mueller@nhm.uio.no

${ }^{2}$ Natural History Museum of London, Cromwell Road, London SW7 5BD, United Kingdom

${ }^{3}$ Vereinigt Zwitterfeld zu Zinnwald Visitor Mine, OT Zinnwald-Georgenfeld, Goetheweg 8, DD-01773 Altenberg, Germany

\begin{abstract}
Magmatic and hydrothermal quartz populations related to the Late-Variscan Zinnwald/Cínovec Sn-W-Li greisen-type deposit in the Eastern Erzgebirge/Krušné Hory (German/Czech Republic) were studied in terms of trace element contents and growth structures visualized by cathodoluminescence. The sample suite represents different populations of hydrothermal greisen quartz and magmatic quartz of the granitic host collected at a 600-m long, lateral section crosscutting the northern part of the deposit at the 750-m level.

The studied quartz populations are characterized by generally low concentrations and low variation of $\mathrm{Al}$ and $\mathrm{Ti}$ indicating relatively constant crystallization conditions (temperature, pressure and fluid chemistry) during ore precipitation. Magmatic and hydrothermal quartz are distinguished by their $\mathrm{Al}, \mathrm{Ti}, \mathrm{Li}$ and Ge concentrations and ratios. Magmatic quartz has commonly higher $\mathrm{Al}(>100 \mathrm{ppm})$ and $\mathrm{Ti}(>3 \mathrm{ppm})$ compared to hydrothermal quartz. The Ge/Al ratio in quartz increases systematically from high to low formation temperatures $\left(664\right.$ to $\sim 400^{\circ} \mathrm{C}$ $=$ temperature range including published data and our estimates) whereas Ti decreases. The Zinnwald albite granite (mineralization host), an albite-rich alkali granite, and massive quartzzinnwaldite greisen contain both magmatic and hydrothermal quartz populations which are distinguishable by their Ge/Al weight ratio: magmatic quartz has a Ge/Al ratio of $<0.008$ whereas hydrothermal quartz a ratio of $>0.008$.
\end{abstract}


Hydrothermal vein quartz related to the $\mathrm{Sn}-\mathrm{W}$ mineralization (Flöze=flat veins and Morgengänge=steep veins) does not show systematic trace element variations along the sampling profile indicating that no significant chemical gradients (in lateral direction) in the ore forming fluid existed. The uptake of $\mathrm{Li}$ in the quartz lattice is limited by the incorporated $\mathrm{Al}$ although the Zinnwald/Cínovec magmatic-hydrothermal system was strongly enriched in Li. The calculated crystallization temperatures of quartz of the Sn-W mineralization applying the TitaniQ thermobarometer reveal crystallisation temperatures ranging from $575 \pm 48^{\circ} \mathrm{C}$ (albite granite), $612 \pm 12{ }^{\circ} \mathrm{C}$ (stockscheider), $610 \pm 23$ (massive greisen), $536 \pm 77^{\circ} \mathrm{C}$ (flat veins), to $516 \pm 58^{\circ} \mathrm{C}$ (steep veins) confirming in general early estimations based on fluid and melt inclusion studies . In economic terms, the hydrothermal quartz (flat and steep veins) with an average total trace element content of $128 \pm 56 \mathrm{ppm}$ has intermediate chemical quality and can serve as a byproduct if colour sorting and other processing steps are applied. Rock-forming quartz of albite granite and massive greisen with an average total trace element content of $233 \pm 127 \mathrm{ppm}$ has medium quality and the disadvantage that quartz contains a high amount of contaminating mineral inclusion, which will be challenging to remove by processing.

\section{Introduction}

Quartz forms under a wide range of temperature and pressure conditions from aqueous fluids and silicate-rich magmas of diverse origin and composition. The diversity results in a great variability of its trace element chemistry reflecting the conditions of the crystal growth environment. For that reason and because of technical developments of microanalytical methods (LA-ICP-MS, SIMS etc.) quartz is more and more utilized to study crystallization processes and parameters in hydrothermal and silica-rich magmatic systems and their transitions (Müller et al., 2002; Breiter et al., 2005, 2012; Rusk 2012). The advantages of using quartz as genetic pathfinder mineral are its almost omnipresence in these environments and its relative strong resistance to post-crystallization alteration (Müller et al., 2000; Monecke et al., 2002; Götze et al., 2004). Variability of concentrations of $\mathrm{Al}, \mathrm{Ti}, \mathrm{Ge}$, and $\mathrm{Li}$ are commonly used for discrimination, classification and genetic interpretations in igneous quartz and to some extent in hydrothermal quartz as well (Lyakhovich, 1972; Suttner and Leininger, 1972; Schrön et al., 1988; Gurbanov et al., 1999; Larsen et al., 2000, 2004; Götze et al., 2004; Jacamon and Larsen, 2009; Müller et al., 
2010a, 2010b; Rusk, 2012). The concentrations of these trace elements are generally controlled by their abundance in the melt, pressure and temperature, physico-chemical conditions of the system, and the partitioning between the co-genetic mineral phases (Gurbanov et al., 1999; Larsen et al., 2004; Jacamon and Larsen, 2009). The parameters controlling the uptake of Ti into the quartz lattice are crystallization temperature and pressure (Huang and Audétat, 2012), whereas $\mathrm{Al}, \mathrm{Ge}$ and Li generally increases with progressing fractionation of the melt. However, parameters controlling the uptake of these elements under transitional magmatic-hydrothermal and purely hydrothermal conditions are less explored and understood (e.g., Rusk, 2012). Analytical methods used for the in situ determination of trace elements in quartz include electron probe microanalysis (EPMA; Müller et al., 2002, 2005; Donovan et al., 2011), secondary ion mass spectrometry (SIMS; Watt et al., 1997; Müller et al., 2003) and laser ablation inductively coupled plasma mass spectrometry (LA-ICP-MS; Flem et al., 2002; Götze et al., 2004; Larsen et al., 2004; Breiter and Müller, 2009; Müller and Koch-Müller, 2009). These analytical techniques have various benefits and drawbacks and they offer most value when integrated with one another and with cathodoluminescence (CL) textural analyses (Rusk, 2012). The advantages of LA-ICPMS over EPMA are lower detection limits in the range of $0.01 \mathrm{ppm}$ to a few ppm for many elements and those of LA-ICP-MS over SIMS the quantification of up to 30 elements simultaneously.

In this study LA-ICP-MS combined with scanning electron microscope cathodoluminescence (SEM-CL) has been applied to study of different igneous and transitional magmatic-hydrothermal quartz populations related the late Variscan granite-hosted Zinnwald/Cínovec Sn-W-Li greisen-type deposit in the eastern Erzgebirge/Krušné Hory across the German/Czech border (Štemprok, 1960, 1961; Bolduan et al., 1967; Čada and Novák, 1974; Dahm and Thomas, 1985; Dolejš and Štemprok, 2001; Seifert et al., 2011; Neßler et al., 2013, 2015). The aim of the study is to evaluate the variability of the trace element concentrations in quartz of different rock types related to the mineralization along a 600-m long section intersecting the northern part of the deposit at the 750-m level. Our study complements the data set of Breiter et al. (2012) and Breiter et al. (2017) which provide a vertical 1600-m section (drill hole CS-1) through the central part of the deposit. The results are used to better understand the parameters which control the trace element distribution in quartz and how this information contributes to a better understanding of the deposit formation in terms of pressure-temperature- 
composition (P-T-X) conditions. In addition, the data are also utilized to evaluate if the quartz of the mineralized veins and the granite host can be used as economic by-product duringfuture exploitation of the Sn-W-Li Zinnwald/Cínovec deposit.

\section{Regional geology}

The Eastern Erzgebirge/Krušné Hory is part of the Saxothuringian Zone of the Variscan orogeny where late- to post-collisional Variscan uplift and exhumation processes accompanied intense felsic (rhyolitic and granitic) magmatism and formed the eastern Erzgebirge volcano-plutonic complex with the Altenberg-Teplice caldera as the major magmatic structure (Seltmann et al., 1996; Štemprok et al., 2003; Figure 1). The pre-Variscan basement of the area, referred to as the Krušné Hory/Erzgebirge Crystalline Complex, comprises various tectonic units of different metamorphic grades that experienced their last metamorphic and deformation imprint during Lower Carboniferous (e.g., O’Brien and Carswell, 1993; Willner et al., 1997; Rötzler et al., 1998; Rötzler and Plessen, 2010). The Eastern Erzgebirge volcano-plutonic complex developed over a period of about $15 \mathrm{Ma}$ (Romer et al., 2007; 2010) during Variscan post-collisional collapse, beginning with the intrusion of the Niederbobritzsch granites at 328-314 Ma (Tichomirowa, 1997; Förster, 1998) and ending with intrusions of topaz-bearing rare metal granites at 326-308 Ma and related Sn-W mineralization (Romer et al., 2007; Seifert et al., 2011; Seifert and Pavlova, 2016). According to Jiránek et al. (1987), Breiter (1997), Breiter et al. (2001) the magmatic history of the Eastern Erzgebirge volcano-plutonic complex includes to following main stages (in the order from old to young):

(I) the emplacement of the Niederbobritzsch and Flaje granite massifs and Telnice granite classified as low-F biotite granites of the Erzgebirge/Krušné Hory (Förster et al., 1998, 1999, Štemprok et al., 2003);

(II) the formation of the $50-\mathrm{km}^{2}$ Tharandter Wald caldera at $320 \pm 4 \mathrm{Ma}$ (Breitkreuz et al. 2009) comprising rhyolitic ignimbrites;

(III) the formation of the $630-\mathrm{km}^{2}$ Altenberg-Teplice caldera comprising the extrusion of the Schönfeld rhyolitic/dacitic ignimbrites, Mikulov rhyolitic ignimbrites (Mikulov beds), Teplice rhyolitic ignimbrites and the intrusion of the Altenberg-Frauenstein microgranite into the caldera collapse structures. The pear-shaped, N-S elongated ring of collapse fractures of the caldera 
were filled by multiple intrusions of the rapakivi-textured porphyritic microgranite of AltenbergFrauenstein (Benek, 1991; Müller and Seltmann, 2002). Hoffmann et al. (2013) acquired a U/Pb zircon age of $326.8 \pm 4.3 \mathrm{Ma}$ for the Mikulov ignimbrite, the initial stage of the Altenberg-Teplice caldera suite. The same authors yielded an age of 308.8 $\pm 4.9 \mathrm{Ma}$ for the Teplice ignimbrite TR1 but stated that the age is not well constrained;

(IV) the youngest stage is represented by the intrusions of topaz-bearing rare-metal granites comprising the Schellerhau granite complex and other small intrusions (Zinnwald-Cínovec, Altenberg, Sadisdorf, Schenkenshöhe, Hegelshöhe, Loupežný, Preisselberg, Knötl). All these intrusions belong to the high-F, low-P Li-mica granites of the Krušné Hory/Erzgebirge which show A-type affinity (Förster et al., 1995; Breiter et al., 1999; Štemprok et al., 2003). Ar-Ar ages of Li-mica of Zinnwald/Cínovec intrusion between 312.6 \pm 2.1 to 314.9 $\pm 2.3 \mathrm{Ma}$ which are interpreted as near-formation ages of Li-mica (Seifert et al., 2011).

Ages of the $\mathrm{Sn}-\mathrm{W}$ mineralization related to the Altenberg-Teplice caldera overlap with the granite ages. Recent Ar-Ar dating of the greisen mineralization at Zinnwald/Cínovec revealed ages of $311.4 \pm 3.0 \mathrm{Ma}$ and 312.5 \pm 3.1 Ma (Seifert and Pavlova, 2016). Romer et al. (2007) obtained ages of $323.9 \pm 2.5$ and $317.9 \pm 2.4 \mathrm{Ma}(2 \sigma$; Re-Os molybdenite $)$ for the $\mathrm{Sn}-\mathrm{W}$ mineralization related to the Altenberg granite. The deposit is considered as co-genetic with the Zinnwald/Cínovec granite intrusion. The Sn-W-Li Zinnwald/Cínovec deposit is in the central eastern part of the Altenberg-Teplice Caldera and hosted by the Zinnwald/Cínovec albite granite. The term Zinnwald/Cínovec albite granite, referred to Zinnwald albite granite in the following, was introduced by Štemprok (1965) and represents an alkali granite with high abundance of magmatic albite.

\section{The Zinnwald/Cínovec Sn-W-Li deposit}

The greisen massive and vein Sn-W-Li mineralization of Zinnwald/Cínovec is situated in the apical part of the Zinnwald pluton beneath the village of Zinnwald-Georgenfeld/ Cínovec at the German-Czech border, $\sim 35 \mathrm{~km} \mathrm{~S}$ of Dresden (Figure 2). The Zinnwald granite intrusion forms a multiply composed, elliptical granite cupola outcropping $1.3 \mathrm{~km}$ in N-S direction and $0.3 \mathrm{~km}$ in E-W direction between the German village of Zinnwald-Georgenfeld and the Czech village of Cínovec (Figure 2). The western contact of the intrusion is steep whereas the southern and 
eastern contact plunges gently with 10 to $30^{\circ}$. The host rock is the Teplice rhyolite. The upper part of the intrusion is formed by Li-F-enriched albite granite (sampled facies) which has in part been strongly greisenized by high-temperature fluids (e.g., Štemprok 1960) and which is underlain by medium-grained protolithionite granite at a depth of $730 \mathrm{~m}$ (beneath Cínovec; Štemprok and Šulcek, 1969, Rub et al., 1983). The Zinnwald pluton is composed of strongly fractionated, slightly peraluminous A-type granites (Seltmann et al., 1998; Štemprok, 1989). In the cupola the Zinnwald albite granite consists of two textural varieties: an older porphyritic and younger medium-grained seriate granite which contains enclaves of the porphyritic granite. Minor dykes of aplite albite granite (albite microgranite), marginal pegmatite (Stockscheider) separate the granite from its host rocks. The stockscheider forms an up to $1.5 \mathrm{~m}$ wide sequence at the contact to the Teplice rhyolite. It has a layered structure consisting of one or several megacrystic bands of K-feldspar and quartz with crystal sizes of up to $20 \mathrm{~cm}$ which alternate with fine-grained, aplitic layers. The comb-like, pluton-inward orientated megacrysts display unidirectional solidification textures. Zinnwaldite is the predominant mica in the albite granite. Feldspars are represented predominantly by albite with low anorthite content $\left(\mathrm{An}_{<3}\right.$; Seltmann et al., 1998) and minor K-feldspar. Main accessories are cassiterite, fluorite, topaz and columbitetantalite in addition to rare bastnaesite, uranpyrochlor, uranmicrolite, strueverite and synchisite (Johan and Johan, 1994; Rub et al., 1998). The protolithionite granite contains on average 0.05 wt.\% $\mathrm{Li}_{2} \mathrm{O}$ and 5.34 wt.\% $\mathrm{K}_{2} \mathrm{O}$. Main accessories are zircon, columbite, monazite, xenotime and rutile; apatite is very rare (Johan and Johan, 2005).

The Sn-W-Li mineralization, which was described in detail by Štemprok $(1960,1961)$, Bolduan et al. (1967) and Čada and Novák (1974), is spatially and genetically associated with the Zinnwald granite cupola. The deposit consists of three structural types of Sn-W ores:

(I) Irregular and massive greisen bodies up to several tens of meters in size within the Zinnwald albite granite (Figures 2B and 4A). The massive greisens are the result of a intense fluid-rockinteraction which affected parts of the Zinnwald albite granite cupola. The commonly sheet-like greisen bodies follow the shape of the granite contact, are most common in the in the apical part of the granite intrusion with decreasing intensity to the flanks but do not extend into the Teplice rhyolite. There are several types of greisens and greisenized granites. The predominant greisens consist of quartz and zinnwaldite or zinnwaldite-quartz-topaz. The greisens contain irregular 
admixtures of sericite, fluorite and potassium feldspar (adularia). Some of the greisens are intensely hematitized. Cassiterite is finely, irregularly dispersed in the greisens and formed cogenetically with the greisens (Štemprok and Šulcek, 1969). Based on field observations the major greisen bodies are considered, in general, to be older than the mineralized quartzzinnwaldite veins described in the following.

(II) Flat-dipping, coarse- to megacrystic quartz-zinnwaldite veins (historically called Flöze) with a thickness of up to $2 \mathrm{~m}$ in the central upper part of the granite cupola (Figures 4B-F). In the Tiefer Bünaustolln the flat veins dip 15 to $40^{\circ} \mathrm{NE}$. The vertical spacing between the individual flat veins varies between 1 and $40 \mathrm{~m}$. Occasionally the veins extend for several tens of meters out of the granite into surrounding the Teplice rhyolite and contain cavities 5 to $20 \mathrm{~cm}$ in size. The quartz veins are commonly accompanied by greisen selvages extending normally not more than $20 \mathrm{~cm}$ into the wall rock. Where the quartz veins cross-cut the massive greisen (type I) these selvages clearly superimpose the massive greisen and are commonly richer in topaz than the massive greisen. The main ore minerals within the veins are cassiterite (up to $2 \mathrm{~cm}$ in size) and wolframite (up to $10 \mathrm{~cm}$ in size) which occur in co-genetic nests either at interstices and cavities of vein quartz or as selvages at the vein contacts. Scheelite (up to $1 \mathrm{~cm}$ ) is a minor ore phase which precipitated mostly on quartz and zinnwaldite in cavities as a late phase. In the apical parts the veins consists occasionally of dense aggregates of stalked, yellow topaz known as pyknite. The flat veins were the major target of the historical mining.

(III) The flat veins (type II) are cross-cut and displaced by sub-vertical, up to $50 \mathrm{~cm}$ wide quartzzinnwaldite dykes historically called Morgengänge and in the following steep veins. The vertical displacement of the flat veins by the steep veins can be several meters. The steep veins exhibit the same style of mineralization as the flat veins. However, the ore grade is principally lower than those of the flat veins. Greisen selvages $(<3 \mathrm{~cm})$ are only occasionally developed.

Štemprok (1960) distinguished in addition K-feldspar (adularia) metasomatism with textures resembling pegmatites, and minor sulphide mineralization with arsenopyrite, galena, sphalerite, tennantite, chalcopyrite, bismuth, bismuthinite, wittichenite, pyrite and opal superimposing the major ore types. Deposition of the sulphides was accompanied by 
sericitization and kaolinization. Supergene alteration affected the sulphide mineralization in the upper part of the cupola resulting in the formation of malachite, philipsbornite, mimetite, olivenite and some rare supergene oxide minerals.

In general, the deposit was formed by repeated influx of magma-derived ore-bearing solutions into the albite granite cupola. During the first stage the fluids penetrated and replaced the albite granite forming massive greisens whereas at the second stage the fluids precipitated mainly flat veins and steep veins of the cupola. The flat and steep veins are also considered as greisen-type mineralization. The fractures were formed apparently by the contraction due crystallization and degassing of the granite in its upper part. The solutions moved to the place of ore deposition from lower levels of the intrusion as testified by the finding of greisens in the deep parts of the granite body (about $1200 \mathrm{~m}$; Seltmann et al., 1998). There was an effective interplay of repeated tectonic movements, fluid migration and precipitation which led to the formation of the deposit and the manifestations of post-magmatic alterations down to the deepest known parts of the intrusion (about 1600 m; Seltmann et al., 1998).

The samples investigated in this study were collected in the Tiefer Bünaustolln adit of the Vereinigt Zwitterfeld mine (Figure 3). The adit exposes the northern German part of the deposit at the 750-m level. The Tiefer Bünaustolln was developed at about 1550 under the name Tiefer Zinnwalder Erbstollen to exploit the Sn-W mineralization hosted by the Zinnwald albite granite. However, tin mining goes back at least until 1378 when the name Zinnwald (Tin Forest) was recorded for the first time. Since that time primary tin ores have been mined with various intensities in the Zinnwald-Cínovec district. The most active period of mining was during the World War I and II. After World War II mining in the Tiefer Bünaustolln was abandoned and continued in the Czech part of the district only. The last mine in the Czech village of Cínovec was closed down in 1990. The amount of extracted tin from the Cínovec-Zinnwald district was about 40,000 t (Štemprok et al., 1995). Between 1990 and 1992 the adit Tiefer Bünaustolln was secured and upgraded for tourism. Recent Li, Sn and W resource estimations for the German and Czech parts of the deposit are provided in Table 1.

\section{Samples and methods}

\subsection{Sampling}


The samples were collected in the Tiefer Bünaustolln adit of the Vereinigt Zwitterfeld zu Zinnwald visitor mine in 2015. The adit cuts through the northern part of the Zinnwald/Cínovec Sn-W-Li deposit at the 750-m level (Figure 3). The adit was chosen as sampling site for the following reasons: (1) the adit allowed sampling of a c. $600 \mathrm{~m}$ long, horizontal, NE-SW-striking profile through the northern part of the deposit; (2) the samples provide a complementary data set to the vertical sampling profile (drill hole CS-1) through the Zinnwald pluton at the Czech side of the deposit studied by Breiter et al. (2017); and (3) there are no surface outcrops of the mineralization and albite granite. The samples include quartz of the Teplice rhyolite phase TR3 (youngest stage), Zinnwald albite granite and its stockscheider, massive quartz-zinnwaldite greisen, vein quartz, and a 3-cm large euhedral quartz crystal from a cavity within e flat vein (Flöz 11; Supplementary Material Table SM1).

All samples were prepared as polished thick (c. $300 \mu \mathrm{m})$ sections clued on standard glass slides $2.8 \times 4.8 \mathrm{~cm}$ for LA-ICP-MS analysis and SEM-CL. The bulk compositions of rocks exposed in the Tiefer Bünaustolln (Teplice rhyolite, Zinnwald albite granite and massive greisen) were determined at ACME laboratories in Vancouver, Canada (ACMELabs, 2017).

\subsection{Scanning electron microscope cathodoluminescence}

The quartz grains were studied with SEM-CL to visualize intra-granular growth zoning and alteration structures and to choose areas for LA-ICP-MS analysis. SEM-CL imaging reveals micro-scale ( $1 \mu \mathrm{m}$ to $1 \mathrm{~mm}$ wide) growth zoning, alteration structures and different quartz generations which cannot be distinguished by other methods. Grey-scale contrasts visualized by SEM-CL are caused by the heterogeneous distribution of lattice defects (e.g., oxygen and silicon vacancies, broken bonds) and lattice-bound trace elements (e.g., Götze et al., 2001). Although the physical background of the quartz CL is not fully understood, the structures revealed by CL give information about crystallisation, deformation and fluid-mediated overprint.

The used CL detector was a Centaurus BS bialkali-type attached to a LEO 1450VP analytical SEM at the Geological Survey of Norway in Trondheim. The applied acceleration voltage and current at the sample surface were $20 \mathrm{kV}$ and $2 \mathrm{nA}$, respectively. The SEM-CL images were collected from one scan of $43 \mathrm{~s}$ photo speed and a processing resolution of $1,024 \times$ 
768 pixels and 256 grey levels. The brightness and contrast of the collected CL images were improved with the PhotoShop software.

\subsection{Laser ablation inductively coupled plasma mass spectrometry}

Concentrations of $\mathrm{Li}, \mathrm{Be}, \mathrm{B}, \mathrm{Mn}, \mathrm{Ge}, \mathrm{Ga}, \mathrm{Rb}, \mathrm{Sr}, \mathrm{Na}, \mathrm{Al}, \mathrm{P}, \mathrm{K}, \mathrm{Ca}, \mathrm{Ti}, \mathrm{Fe}, \mathrm{Sb}, \mathrm{Zn}$, and U were determined by LA-ICP-MS. The quartz samples were prepared as surface-polished, $300-\mu \mathrm{m}$ thick sections mounted on standard glass slides. The analyses were undertaken on a doublefocusing sector field inductively coupled plasma mass spectrometer, HR-SF-ICP-MS, model ELEMENT XR from Thermo Scientific at the Geological Survey of Norway in Trondheim, Norway. The instrument is linked to a New Wave UP193FX ESI Excimer laser probe. The 193$\mathrm{nm}$ laser had a repetition rate of $15 \mathrm{~Hz}$, a spot size of $75 \mu \mathrm{m}$, and energy fluence about 5 to 6 $\mathrm{J} / \mathrm{cm}^{2}$ on the sample surface. A continuous raster ablation on an area of approximately $150 \times 300$ $\mu \mathrm{m}$ was applied. The approximate depth of ablation was between 10 and $50 \mu \mathrm{m}$. A Hitachi CCD video camera, type KP-D20BU, attached to the laser system, was used to observe the laser ablation process and to avoid microscopic mineral and fluid inclusions. The carrier gas for transport of the ablated material to the ICP-MS was He mixed with Ar. The isotope ${ }^{29} \mathrm{Si}$ was used as the internal standard applying the stoichiometric concentration of $\mathrm{Si}$ in $\mathrm{SiO}_{2}$. External multistandard calibration was performed using the reference materials NIST SRM 610, 612, 614, and 1830. In addition, the applied reference materials include the BAM No. 1 amorphous $\mathrm{SiO}_{2}$ glass from the Federal Institute for Material Research and Testing in Germany and the Qz-Tu synthetic pure quartz monocrystal provided by Andreas Kronz from the Geowissenschaftliches Zentrum Göttingen (GZG), Germany. Certified, recommended, and proposed values for these reference materials were taken from Jochum et al. (2011) and from the certificates of analysis where available. For the calculation of P concentrations, the procedure of Müller et al. (2008) was applied. Each measurement comprised 15 scans of each isotope, with the measurement time varying from $0.15 \mathrm{~s} / \mathrm{scan}$ for $\mathrm{K}$ in medium mass resolution mode to $0.024 \mathrm{~s} / \mathrm{scan}$ of, for example, $\mathrm{Li}$ in low mass resolution mode. An Ar blank was run before each reference material and sample measurement to determine the background signal. The background was subtracted from the instrumental response of the reference material/sample before normalization against the internal standard in order to avoid effects of instrumental drift. This was carried out to avoid memory 
effects between samples. A weighted least squares regression model, including several measurements of the six reference materials, was used to define the calibration curve for each

element. Ten sequential measurements on the BAM No.1 $\mathrm{SiO}_{2}$ quartz glass were used to estimate the limits of detection (LOD) which were based on triple standard deviation $(3 \sigma)$ of the 10 measurements.

\section{Results}

\subsection{Whole rock chemistry}

Bulk analyses of rocks exposed in the adit Tiefer Bünaustolln (Teplice rhyolite, Zinnwald albite granite and massive greisen) are provided in Table 2 . These rocks comprise the Teplice rhyolite phase TR3 (host rock of the Zinnwald granite pluton), albite granite and massive quartzzinnwaldite greisen (strongly greisenized albite granite). In Figure 5 main and trace element data are plotted together with published data from Cocherie et al. (1991), Seltmann et al. (1998), and Breiter et al. (2012).

The mildly peraluminous, high-K calc-alkaline Teplice rhyolite phase TR3, being the host rock of the Zinnwald granite cupola and the Sn-W-Li mineralization, has the most primitive composition compared to the other rocks exposed in the Tiefer Bünaustolln with relatively high $\mathrm{Ti}, \mathrm{Mg}, \mathrm{K}$ and $\mathrm{P}$ and low $\mathrm{Al}, \mathrm{Mn}, \mathrm{Li}$ and $\mathrm{F}$ concentrations. In the context of the evolution of the Altenberg-Teplice caldera the Teplice rhyolite TR3, being the last effusive stage of the Teplice formation prior to the caldera collapse, represents chemically a moderately evolved rhyolitic sequence (Breiter, 1997; Breiter et al., 2001; Müller et al., 2005). The magmatic suite of the Zinnwald pluton including the greisens is enriched in F, Li, Cs, Rb, Th, K, Nb, Ta, Y, Yb, Sn, W, and depleted in $\mathrm{Ti}, \mathrm{Mg}, \mathrm{Ba}, \mathrm{Sr}$ and $\mathrm{Zr}$. Distinct similarities in the trace element and REE patterns (Figures 5C and D) imply a common source of the Teplice rhyolite and the Zinnwald granite melts as suggested already by Müller et al. (2005). The differentiation degree progresses almost consistently from the Teplice rhyolith, protolithionite granite, albite granite, albite microgranite towards the massive quartz-zinnwaldite greisen reflected by increasing $\mathrm{Li}, \mathrm{Mn}, \mathrm{F}, \mathrm{Rb}, \mathrm{Nb}, \mathrm{Ta}, \mathrm{Sn}$, $\mathrm{W}$ and decreasing $\mathrm{Ti}, \mathrm{Sr}, \mathrm{Zr}, \mathrm{Ba}, \mathrm{LREE}$. The $\mathrm{Li}_{2} \mathrm{O}$ content of the greisen is higher (mean $0.63 \pm$ 
0.45 wt. $\% ; n=3)$ than that of the Zinnwald albite granites $(0.29 \pm 0.35$ wt. $\% ; n=12$; Cocherie et al., 1991; Seltmann et al., 1998; Breiter et al., 2012 and this study). The albite granite has higher average Ta (mean $43.7 \pm 19.8$ ppm; $n=12)$ and $\mathrm{W}(119.1 \pm 378.7 \mathrm{ppm} ; \mathrm{n}=12)$ than the greisen $(30.1 \pm 12.9$ ppm Ta; $21.8 \pm 16.6 \mathrm{ppm} \mathrm{W} ; \mathrm{n}=3)$. High average $\mathrm{W}$ of albite granite is caused by a concentration spike of sample CS-1 162.3 m (2511 ppm W) analyzed by Cocherie et al. (1991). The Zinnwald albite granite samples 2.6A, 2.7 and 4.8A were affected by greisenization as indicated by low $\mathrm{Na}_{2} \mathrm{O}$ and high LOI (Table 2). Geochemically, the protolithionite granite and albite granite have a strong A-type signature with $10^{4} \cdot \mathrm{Ga} / \mathrm{Al}>5$ (by mass).

\subsection{Microstructures of quartz visualized by SEM-CL}

\section{Teplice rhyolite (host rock)}

The Teplice rhyolite (phase TR3) is the host rock of the Zinnwald granite cupola and contains magmatic quartz phenocrysts $(1-5 \mathrm{~mm})$ with complex concentric growth zoning previously described by Müller et al. (2005) and Breiter et al. (2012; Figure 6A). The boundaries of the growth zones are subrounded. In the investigated sample the growth zone boundaries are blurred compared to sharp boundaries observed by Müller et al. (2005) and Breiter et al. (2012). This is presumably caused by increased Ti diffusive migration (Ti defects are mainly responsible for the observed zoning in igneous quartz; e.g. Müller et al. 2000) due the contact metamorphism by the albite granite. The primary zoning is intensively overprinted by secondary, nearly nonluminescent (black in SEM-CL) quartz forming a dense network of healed microfractures.

\section{Zinnwald albite granite}

Quartz from the Zinnwald albite granite forms drop-like crystals up to $5 \mathrm{~mm}$ in size with amoeboid grain boundaries. The crystals exhibit weakly contrasted, oscillatory growth zoning which continues into the amoeboid crystal margin (Figure 6B). The boundaries of the oscillatory growth zones are straight, with sharp edges. The luminescence intensity is generally higher in the crystal cores and decreases towards the crystal margin. The outermost growth zones exhibit very weak CL and growth zoning can be hardly recognized. The crystals contain commonly concentrically arranged inclusions of euhedral albite ("snow-ball” texture; Beus, 1962; Müller and Seltmann, 1999). 


\section{Stockscheider (endocontact pegmatite)}

The pegmatitic quartz of the stockscheider has fernlike, dendritic crystal shape. The crystals, which are up to $8 \mathrm{~cm}$ long, form comb-like textures perpendicular to the contact with the Teplice rhyolite (Figures 6C, D). The stockscheider quartz has dull CL and does not show primary growth zoning but exhibits a dense network of microfractures healed with nearly nonluminescent, secondary quartz.

\section{Massive greisens within the Zinnwald albite granite}

The dull-luminescent, massive greisen quartz shows oscillatory growth zoning of low contrast (Figures 7A and B) similar to those of the snowball-textured quartz but with lower CL intensity. The CL reveals that the massive greisen quartz consists of clusters of individual, more or less isomorphic, "drop-like"quartz grains 1 to $10 \mathrm{~mm}$ in size. The grains commonly display relics of former rock-forming minerals of feldspars or snow-ball textured quartz in the crystal cores, indicating that these relics served as nuclei for the greisen quartz. Secondary structures (healed microfractures) are common but much less abundant than in other quartz varieties.

\section{Hydrothermal flat and steep veins}

Quartz of the hydrothermal veins is megacrystic with crystals up to $30 \mathrm{~cm}$ in length. The dull luminescent vein quartz shows fine oscillatory growth zoning with low contrast (Figure 7C). In general the crystals grew perpendicular to the vein contacts. Occasionally, small (1-5 mm) isomorphic, "drop-like" crystals occur in the central part of the veins (Figure 7D). These crystals form clusters and nucleated at sericite and feldspar/kaolinite. Open cavities in the flat veins contain commonly euhedral, up to $20 \mathrm{~cm}$ long whitish to smoky crystals. The 5 -cm long smoky crystal investigated in this study is free of oscillatory zoning but shows sector zoning (Figure 7E). Secondary structures, represented by microfractures healed with nearly non-luminescent or bright luminescent quartz, are less common as in the magmatic and massive greisen quartz.

\subsection{Quartz chemistry}

\section{Chemical variability among rock types}


The complete list of trace element concentrations ( $\mathrm{Li}, \mathrm{Be}, \mathrm{B}, \mathrm{Mn}, \mathrm{Ge}, \mathrm{Rb}, \mathrm{Sr}, \mathrm{Al}, \mathrm{Ti}$, and Fe) in quartz of the investigated samples is given in the Supplementary Material Table SM2. Average contents are listed in Table 3. Concentrations of $\mathrm{Na}, \mathrm{K}, \mathrm{Ca}, \mathrm{P}, \mathrm{Ga}, \mathrm{Sb}, \mathrm{Zn}$, and $\mathrm{U}$ are generally below the limits of detection $(7,13,16,3,0.05,0.02,1.5$, and $0.01 \mathrm{ppm}$, respectively) and are, thus, not provided. In Figure 8 concentrations of Al, Ti, Li and Ge are plotted. These elements commonly occur in elevated concentrations in quartz and their variation reflect, in general sense, the P-T-X conditions of the melt and fluids from which the crystals growth.

Aluminium concentrations vary between 10 and $561 \mathrm{ppm}$. Its average content increases from TR3 (oldest rock; $158 \mathrm{ppm}$ ) to the stockscheider (456 ppm) but drops in the greisen quartz down to $189 \mathrm{ppm}$ and further down to 95 and $91 \mathrm{ppm}$ in the flat and steep veins (youngest rocks; Table 3). The Ti concentrations range from $<0.5$ to $15.1 \mathrm{ppm}$. The average values decrease more or less continuously from the Teplice rhyolite (14.5 ppm), Zinnwald albite granite (4.1 ppm), stockscheider (5.6 ppm), greisen $(5.0 \mathrm{ppm})$ to the veins (3.2 and $2.1 \mathrm{ppm}$, respectively). The continuous decrease reflects decreasing crystallization temperatures and pressures during magmatic-hydrothermal evolution. It should be noted that Müller et al. (2005) and Breiter et al. (2012) detected up to $123 \mathrm{ppm}$, respectively, $105 \mathrm{ppm}$ Ti in bright luminescent growth zones of the quartz phenocrysts in TR3. Compared to the average abundances in thequartz of flat veins, the Ti concentration of sample 1.11 (Flöz 7) is exceptionally high (11.4 ppm; $\mathrm{n}=3$ ). In order to confirm the concentration spike the locality was resampled (samples $1.11 \mathrm{x}, 1.11 \mathrm{y}$ ). One sample was taken exactly at the same site (1.11x) and the other sample (1.11y) $50 \mathrm{~cm}$ away. Sample $1.11 \mathrm{x}$ has similar high Ti concentration of $11.4 \mathrm{ppm}(\mathrm{n}=3)$, whereas sample $1.11 \mathrm{y}$ has a lower content of $8.0 \mathrm{ppm}$, which is nevertheless significantly higher than the other vein samples. . In the Al versus Ti plot (Figure 8A) quartz of oldest magmatic rock (Teplice rhyolite) has highest Ti concentrations which decrease in the protolithionite granite and albite granite accompanied by increasing $\mathrm{Al}$ concentrations. The stockscheider quartz has highest Al concentrations representing the most evolved and youngest magmatic facies. This trend follows the established quartz composition trend of the Altenberg-Teplice caldera (Müller et al., 2005; Breiter et al., 2012 , 2017). The greisens and veins plot mostly outside the magmatic trend towards lower Al and Ti. However there is an overlap which does not allow a clear distinction between magmatic and hydrothermal quartz (Figures $8 \mathrm{~A}$ and $\mathrm{B}$ ). 
The Li content in quartz of the albite granite, greisens, and veins is generally low $(<10 \mathrm{ppm})$ except some concentration spikes $>20 \mathrm{ppm}$ Li (albite granite sample 2.6A, vein samples 1.3, 3.1A-C, 3.4). Quartz phenocrysts in the Teplice rhyolite and stockscheider quartz have highest average Li of $25.4 \pm 2.3 \mathrm{ppm}$ and $22.9 \pm 7.8 \mathrm{ppm}$, respectively, compared to the other rock types. In the $\mathrm{Al}$ versus Li plot the samples show weak positive linear correlations with different slopes for different rock types (Figure 8C). The correlations are due to substitution $\mathrm{Si}^{4+} \leftrightarrow \mathrm{Al}^{3+}+\mathrm{Li}^{+}$, where $\mathrm{Al}$ replaces $\mathrm{Si}$ in the tetrahedral site and $\mathrm{Li}^{+}$enters interstitial lattice position (e.g. Dennen, 1966). Data which plot along the 1:1 Al:Li molar ratio line indicate that almost all $\mathrm{Al}^{3+}$ defects are charge-compensated by $\mathrm{Li}^{+}$; alternative charge compensator are $\mathrm{H}^{+}, \mathrm{Na}^{+}$, or $\mathrm{K}^{+}$. Magmatic quartz of the Teplice rhyolite and hydrothermal quartz of the veins plot closest to the 1:1 line. Germanium concentrations vary from 0.05 to $2.49 \mathrm{ppm}$, which corresponds to the range described from other magmatic systems (e.g. Jacamon and Larsen, 2009). Quartz of the albite granite, stockscheider and flat veins has highest average Ge (1.5-1.6 ppm; Table 3). In the Al versus Ge plot both elements show rock-specific correlations with different slopes of the regression lines (Figure 8D). The slopes increase from magmatic towards hydrothermal indicating that hydrothermal quartz increasingly incorporates more Ge in lieu of Al. In this way magmatic quartz might be distinguished from hydrothermal quartz in Ge-rich systems. Fe concentrations above the detection limit $(>1.0 \mathrm{ppm})$ are observed only in TR3 (mean $4.6 \mathrm{ppm}$ ) and stockscheider (mean $7.5 \mathrm{ppm}$ ). Manganese concentrations are typically higher in igneous quartz than in hydrothermal quartz (Table 3). Beryllium concentrations are in the range of $<0.03$ to $1.78 \mathrm{ppm}$, being highest in the stockscheider quartz $(0.81 \pm 0.07 \mathrm{ppm})$. Boron concentrations are relative consistent (around $1 \mathrm{ppm}$ ), except the stockscheider quartz with $2.1 \mathrm{ppm}$. Average $\mathrm{Rb}$ concentrations vary between 0.03 to $6.60 \mathrm{ppm}$, being highest in the stockscheider quartz $(6.60 \pm 2.47 \mathrm{ppm})$. Strontium concentrations are generally $<0.1 \mathrm{ppm}$ except stockscheider quartz (mean $0.3 \mathrm{ppm}$ ) and quartz of the steep veins (mean $0.2 \mathrm{ppm}$ ). Considering the average contents, stockscheider quartz (very high in $\mathrm{Be}, \mathrm{B}, \mathrm{Mn}, \mathrm{Rb}, \mathrm{Sr}, \mathrm{Al}$, and $\mathrm{Fe}$ ) displays major differences relative to the ensemble of the other samples (Table 3).

Spatial variation of quartz chemistry in flat veins was investigated along a 600-m long section through the northern part of the Zinnwald/Cínovec Sn-W-Li deposit at the $750 \mathrm{~m}$ adit level. It should be considered that the lateral sampling profile crosscut several different flat veins which dip 15 to $40^{\circ} \mathrm{NE}$. There is no systematic change in the Al, Ti, Ge, and B concentrations in 
quartz from the contact to the interior of the deposit (Standard deviations are higher than the variation of the average values; Figure 9).

The graphs in Figure 10 illustrate the variability of $\mathrm{Al}, \mathrm{Ti}, \mathrm{Ge}$, and $\mathrm{Li}$ in three quartz samples taken from the top, centre, and bottom of a flat, $60-\mathrm{cm}$ thick vein (Flöz 11). The variation of these elements within one quartz sample $(3.1 \mathrm{~A}-\mathrm{C})$ is in the same range as the variability of all three samples ("entire" vein) suggesting that there is no significant chemical gradient across the vein.

A 2-cm long, euhedral quartz crystal from a cavity in a flat vein (Flöz 11) was measured across the crystal to check the intra-granular variation of trace elements (Figure 7E). The crystal was chosen because it shows primary growth zoning revealed by SEM-CL. Li decreases from the core to the rim of the crystal, whereas Al increases slightly. All other trace elements do not show systematic variations between core and rim of the crystal.

\section{Discussion}

\section{Causes of the chemical diversity of quartz in the Zinnwald/Cinovec Sn-W-Li deposit}

Rusk (2012) showed that concentrations of Al and Ti vary systematically among epithermal deposits, orogenic Au deposits and porphyry-type deposit and can be used to fingerprint the type of ore deposit based on the trace element composition. Figure 11A shows the logarithmic Ti and Al plot with compiled data of c. 30 porphyry-type, orogenic Au, and epithermal deposits (colourshaded fields) according to Rusk (2012) compared with data from the Zinnwald/Cínovec Sn-WLi deposit. Data from Zinnwald/Cínovec overlap with orogenic Au and porphyry-type deposits. Porphyry-type and granite-related rare metal deposits are both transitional magmatic-

hydrothermal systems (orogenic Au deposits not) and the composition of quartzin these systems appears to be similar. The Zinnwald/ Cínovec quartz exhibits, however, significant differences with those in the porphyry-type, and we now discuss the possible reasons for these."

First, the lower Ti in Zinnwald/Cínovec quartz, compared to the porphyry-type quartz,indicates lower crystallization temperature and/or pressure and/or lower Ti activity $a \mathrm{TiO}_{2}$ of the melt or fluid (Wark and Watson, 2006; Huang and Audétat, 2012). Previous calculations 
of the crystallisation temperature and pressure of the Zinnwald albite granite by Thomas, (1994) and Thomas et al. (2005) based on melt and fluid inclusion microthermometry revealed 627 to $664{ }^{\circ} \mathrm{C}$ and $1.1 \mathrm{kbar}$, respectively. Estimations of the quartz crystallization temperatures of the flat veins utilizing fluid inclusion microthermobarometry indicate formation temperatures of the main Sn-W mineralization between $\sim 400$ to $510^{\circ} \mathrm{C}$ (Ďrišová et al., 1979; Sushchevskaya et al., 1996; Graupner et al., 2005; Albrecht, 2017) and pressures of 0.4 to $1.1 \mathrm{kbar}$ (Sushchevskaya et al., 1996; Webster et al., 2004; Albrecht, 2017). These estimates are based on fluid inclusion studies in both cassiterite and quartz (Ďurišová et al., 1979; Sushchevskaya et al., 1996; Webster et al., 2004; Graupner et al., 2005) and on the TitaniQ geothermobarometry (Albrecht, 2017). Because the formation of massive greisen postdates the granite crystallization and predates the vein formation, the crystallization temperatures of the massive greisen quartz were probably in the range of 510 to $627^{\circ} \mathrm{C}$, considering the published temperature estimates given above.

Albrecht (2017) calculated $a \mathrm{TiO}_{2}$ of 0.11 for the Zinnwald albite granite melt based on melt inclusion data provided by Thomas et al. (2005). However, $a \mathrm{TiO}_{2}$ of the greisen- and veinforming fluids is likely to be $\leq 0.11$ because Ti preferentially partitions into the melt during fluid-melt separation (Lester et al., 2013). The calculated crystallization temperatures of quartz applying the TitaniQ thermobarometer by Huang and Audétat (2012) are $575 \pm 48^{\circ} \mathrm{C}$ for the albite granite, $612 \pm 5^{\circ} \mathrm{C}$ for the stockscheider, $610 \pm 23^{\circ} \mathrm{C}$ for the massive greisen, $536 \pm 77^{\circ} \mathrm{C}$ for the flat veins, and $516 \pm 58^{\circ} \mathrm{C}$ for the steep veins. Temperatures of the greisen and veins are minimum crystallization temperatures due the uncertainty of the $a \mathrm{TiO}_{2}$ in the hydrothermal fluid. Nevertheless, the temperatures determined with TitaniQ thermobarometer are in good agreement with temperatures calculated by microthermometry of fluid inclusions.

Compared to other deposit types and other hydrothermal mineralization (e.g., Landtwing and Pettke, 2005; Jourdan et al., 2009), the second main difference exhibited by the Zinnwald/Cínovec system is the generally low Al content in quartz and its little variation, in particular of the flat and steep veins (Figure 11A). The controls on Al concentrations in quartz are still under debate (e.g. Rusk, 2012). Breiter and Müller (2009) stated that there is no correlation between the $\mathrm{Al}$ in igneous quartz and the $\mathrm{Al}$ content and peraluminousity of the parental melt, which is supported by our data. Greisens have a higher alumina saturation index $\left(\mathrm{ASI}=\right.$ molar $\mathrm{Al}_{2} \mathrm{O}_{3} /\left(\mathrm{CaO}+\mathrm{Na}_{2} \mathrm{O}+\mathrm{K}_{2} \mathrm{O}=2.6-4.2\right)$ than the albite granite $(\mathrm{ASI}=1.0-3.5)$ but both rocks contain quartz with similar Al. Rusk et al. (2008) and Müller et al. (2010b) suggested 
that the variations of $\mathrm{Al}$ concentration ( $5 \mathrm{ppm}$ to $\sim 5000 \mathrm{ppm}$ ) in hydrothermal quartz related to porphyry deposits may result from fluctuations of the fluid $\mathrm{pH}$ during the quartz crystallisation. In general, the high $\mathrm{Al}$ concentration in quartz may reflect the ratio of the total $\mathrm{Al}^{3+}$ and $\mathrm{Si}^{4+}$ activities the hydrothermal fluid, which is strongly dependent on fluid temperature and $\mathrm{pH}$ (Pokrovskii and Helgeson, 1995; Salvi et al., 1998; Götte, 2016). The minimum of the total Al/Si ratio in hydrothermal solutions shifts to lower $\mathrm{pH}$ at higher temperatures up to $\sim 200^{\circ} \mathrm{C}$ (Götte, 2016) suggesting that elavated $\mathrm{pH}$ favour $\mathrm{Al}^{3+}$ uptake of quartz in low-temperature $\left(\leq 200^{\circ} \mathrm{C}\right)$ environments (Perny et al., 1992; Götte, 2016). Anyway, we interpret the little variation and general low Al concentrations of the investigated quartz as crystallization of the Zinnwald/Cínovec deposit at more stable conditions and presumably relative stable $\mathrm{pH}$ compared to porphyry systems.

The decreasing Ti content and increasing Al content (i.e., the increase in the Al/Ti-ratio) in igneous quartz (Teplice rhyolite, protolithionite granite, albite granite, stockscheider) shown in Figure $8 \mathrm{~A}$ is one of the hallmarks of progressive magma differentiation (Müller et al., 2002, 2010a; Breiter and Müller, 2009). Individual magmatic rock types of the Zinnwald/Cínovec SnW-Li deposit (Teplice rhyolite, albite granite, stockscheider) follow this Al-Ti trend, whereas the majority of the hydrothermal (magmatic-derived) quartz data (massive greisens, flat and steep veins) plot outside this trend towards lower $\mathrm{Al}$ and Ti. The dataset published by Breiter et al. (2017) shows a similar pattern. There is an overlap of data for massive greisen and veins with the albite granite data. The overlap is caused by the occurrence of both magmatic and hydrothermal quartz generations in the albite granite and massive greisens as revealed by the CL observations. The outermost growth zones of the snow-ball textured quartz in the albite granite corresponds in $\mathrm{CL}$ and trace element content the greisen quartz. In the massive greisen relics of snow-ball textured quartz represent the remains magmatic quartz.

In particular the data set of massive greisens and albite granite shows the strongest overlap (Figure 8B). The overlap is caused that the albite granite exposed in the Bünaustolln is slightly greisenized to different degrees and thus contains both magmatic quartz (snowball-textures quartz) and greisen quartz. On the other hand, massive greisen contains relics of magmatic quartz which were not completely replaced. Massive greisen is overprinted albite granite contains both remains of magmatic quartz overgrown and/or replaced by greisen quartz. Both quartz populations (snowball-textured quartz and greisen quartz) can be hardly distinguished in SEM- 
CL due to similar CL properties. Similar observations have been made by Breiter et al. (2017). Puzzling are the exceptional high Ti concentrations (10 to $13 \mathrm{ppm}$ ) of vein quartz sample 1.11 (Flöz 7). This anomaly is very limited in dimension (about $0.5 \mathrm{~m}$ in lateral extension of the 35 $\mathrm{cm}$ thick vein. High crystal growth rate, which favors high uptake of trace elements at temperatures $>400^{\circ} \mathrm{C}$ (e.g., Martin and Armington, 1983), can be excluded, because in that case other trace elements should exhibit similar anomalies. The stockscheider quartz being enriched in all measured trace elements (except Ti) is interpreted as an example of high trace element incorporation due to disequilibrium growth during high growth rate in a strongly undercooled melt at the albite granite contact. The high growth rate is documented by the dendritic crystal habit of the stockscheider quartz (Figure 6C, D). The high Ti in sample 1.11 is maybe an inherited signature of the magmatic precursors.

Lithium concentrations in quartz of the Zinnwald/Cínovec deposit are low compared to other Li-rich magmatic systems as for example, the Tres Arroyos granite-pegmatite system in Spain (Garate-Olave et al., 2017) or the Li pegmatites of Borborema, Brazil (Beurlen et al., 2011). Quartz of the Tres Arroyos granite suite contains 35 to $71 \mathrm{ppm} \mathrm{Li}$ and related pegmatites up to $134 \mathrm{ppm} \mathrm{Li}$. The Borborema pegmatites contain quartz with up to $150 \mathrm{ppm} \mathrm{Li}$. The low $\mathrm{Li}$ concentrations in quartz of albite granite, greisens, and veins is surprising because these rocks are enriched in $\mathrm{Li}_{2} \mathrm{O}$ (Figure 5B) with zinnwaldite as the major carrier containing up to 4 wt.\% $\mathrm{Li}_{2} \mathrm{O}$ (Johan et al., 2012). Zinnwaldite might serve as a Li moderator. However, as shown for the Tres Arroyos and Borborema pegmatites Li micas do not act necessarily as buffers of the Li content in quartz (Beurlen et al., 2011; Garate-Olave et al., 2017). We interpret that the low Li content to be the result of the limited $\mathrm{Al}$ content in the quartz lattice. Lithium serves as charge compensator for substitutional $\mathrm{Al}^{3+}$ defects $\left(\mathrm{Si}^{4+} \leftrightarrow \mathrm{Al}^{3+}+\mathrm{Li}^{+}\right)$, where $\mathrm{Al}$ replaces $\mathrm{Si}$ in the tetrahedral site and $\mathrm{Li}^{+}$enter in interstitial lattice position (e.g., Dennen, 1966). Results of our and previous studies imply that the $\mathrm{Li}: \mathrm{Al}$ atomic ratio in quartz does not exceed 1. Similar observations had been made by Jordan et al. (2009), Müller and Koch-Müller (2009), Breiter and Müller (2009), Beurlen et al. (2011) and Garate-Olave et al. (2017). Thus, the Li uptake by quartz is limited by the amount of $\mathrm{Al}^{3+}$ which substitutes $\mathrm{Si}^{4+}$.

Germanium is compatible in quartz and substitutes for $\mathrm{Si}^{4+}$. Because of the compatibility the amount of lattice-bound Ge is primarily controlled by the amount of available Ge in the melt or fluid. The Zinnwald/Cínovec system is strongly enriched in Ge (2.8-3.1 ppm in the albite 
granite whole rock; Breiter et al., 2012) whereas the average concentration of Ge in the upper crust is 1.4 ppm (Rudnick and Gao, 2004). The enrichment is reflected in the quartz chemistry with high average Ge concentrations in quartz ranging from $0.9 \mathrm{ppm}$ (steep veins) to $1.6 \mathrm{ppm}$ (Stockscheider and greisens). The decreasing average Ge in hydrothermal quartz (greisen to steep veins) is according to Pokrovski and Schott (1998) explained by the decreasing Ge solubility in the hydrothermal fluid with decreasing temperature. One of the most significantoutcomes of this study is the revealed increase of the Ge/Al ratio from magmatic to hydrothermal quartz (except stockscheider) despite that the Ge concentrations in quartz decrease with decreasing formation temperature (Table 3). In other words, Ge becomes more preferably incorporated as $\mathrm{Al}$ in quartz at hydrothermal conditions. Using the $\mathrm{Ge} / \mathrm{Al}$ ratio magmatic and hydrothermal quartz of the Zinnwald/Cínovec Sn-W-Li deposit can be clearly distinguished from each other even if both hydrothermal and magmatic quartz populations occur in the massive greisens as well as in the albite granite) as discussed above (Figure 8D). The magmatic and hydrothermal quartz generations in both rocks are distinguishable by their Ge/Al weight ratio: magmatic quartz has a Ge/Al ratio of $<0.008$ whereas hydrothermal quartz a ratio of $>0.008$.

\section{Economic implications}

The Zinnwald/Cínovec Sn-W-Li deposit is currently a target of Li exploration both on German and Czech territory. Given that the deposit may be mined in future for Li with Sn and W, quartz separates might be used as a by-product to minimize the waste volume and to increase the profitability. The vein quartz has lowest total trace element contents, which range from 20 to 250 ppm (mean $128 \pm 56 \mathrm{ppm}$ ). These concentrations classify the hydrothermal quartz as chemical "intermediate quality" according to Harben (2002) and Müller et al. (2012). Other advantages of

exploiting the vein quartz are the large crystal size $(>1 \mathrm{~cm})$, the low content of mineral inclusions within the crystals, and distinct whitish to bright greyish colouration allowing colour sorting. Disadvantage is low volume of the vein quartz, 1 to $3 \%$ of the granite cupola which is restricted to the uppermost 100 meters of the deposit. The albite granite and greisen quartz has highly variable total trace element contents that range from 67 to 440 ppm (mean $233 \pm 127$ ppm). These attributes assign the quartz to transitional intermediate to medium quality according to Harben (2002). Due to the high content of mineral inclusions in albite granite and greisen quartz 
(e.g. Figure 6B) it is expected that only medium quality quartz product will be achieved applying several processing steps (e.g. Larsen and Kleiv 2015, 2016).

\section{Conclusions}

The results of the study and the implications for the genesis and the economy of the Zinnwald/Cínovec Sn-W-Li deposit are summarized as follows:

- The magmatic and hydrothermal quartz populations related to the late Variscan Zinnwald/Cínovec Sn-W-Li greisen-type deposit are characterized by general low contents and low variation range of $\mathrm{Al}$ and $\mathrm{Ti}$ compared to porphyry-type deposits. The low variation indicates relative consistent crystallization conditions (temperature, pressure and fluid chemistry) during ore precipitation.

- Within the deposit magmatic and hydrothermal quartz populations are distinguished by their Al, Ti, Li and Ge concentrations and ratios. Magmatic quartz has higher Al and Ti concentrations compared to hydrothermal quartz. The Ge/Al ratio in quartz increases systematically from high to low temperatures of quartz crystallization $\left(664\right.$ to $\sim 400^{\circ} \mathrm{C}=$ temperature range including published data and our estimates) even though Ge decreases with decreasing formation temperature. Titanium decreases as well with decreasing temperatures. The albite granite and massive quartz-zinnwaldite greisen contain both magmatic and hydrothermal quartz populations which are distinguishable by the $\mathrm{Ge} / \mathrm{Al}$ and $\mathrm{Li} / \mathrm{Al}$ ratios. It should be tested if other mineralized systems show similar trace element trends.

- Fast crystal growth rates as indicated by dendritic crystal habits of the stockscheider quartz, which crystallized at the contact of the Zinnwald granite cupola, result in exceptional high trace element concentrations and, thus, disequilibrium growth. 
- The chemistry of quartz in hydrothermal flat and steep veins related to the Sn-W mineralization does not show systematic variation along a $600 \mathrm{~m}$ long, lateral profile crosscutting the northern part of the deposit. Thus, crystallization conditions were supposedly relatively consistent during precipitation of quartz and associated ore minerals (wolframite, cassiterite).

- The maximum concentration of $\mathrm{Li}$ in the quartz lattice is limited by the amount of $\mathrm{Al}$ necessary for charge compensation despite that the parental melts or fluids were highly enriched in $\mathrm{Li}$. The maximum of the atomic $\mathrm{Al}: \mathrm{Li}$ in hydrothermal and magmatic quartz is 1 .

- The calculated crystallization temperatures of quartz of the Sn-W mineralization applying the TitaniQ thermobarometer by Huang and Audétat (2012) are $536 \pm 77^{\circ} \mathrm{C}$ for the flat veins and $516 \pm 58^{\circ} \mathrm{C}$ for the steep veins, somewhat higher than published estimations of the formation temperatures $\left(\sim 400\right.$ to $\left.510^{\circ} \mathrm{C}\right)$ based on fluid inclusion microthermobarometry.

- The study provides the first estimates of the formation temperature of the stockscheider quartz $612 \pm 5^{\circ} \mathrm{C}$ and massive greisen $610 \pm 23^{\circ} \mathrm{C}$. The latter represents the formation temperature of the main Li(-mica) mineralization.

- In economic terms, the hydrothermal vein quartz with an average total trace element content of $128 \pm 56 \mathrm{ppm}$ has intermediary chemical quality and can serve as a by-product if colour sorting and other processing steps are applied. Rock-forming quartz of the Zinnwald albite granite and massive greisen with an average total trace element content of $233 \pm 127$ ppm has medium quality and in addition contains many mineral inclusions which may complicate the processing.

\section{Acknowledgements}


We like to thank Øyvind Skår from the Geological Survey of Norway in Trondheim who helped to perform the quartz analyses. We are grateful to Christian Marignac, Thomas Götte, Robert Ayuso, and an anonymous reviewer for their constructive comments and suggestions which have greatly improved the quality of the manuscript.

\section{References}

ACMELabs, 2017. Bureau Veritas Mineral Laboratories. <http://acmelab.com/> Accessed 27 July 2017.

Albrecht, M., 2017. The role of the fluid composition in the formation of hydrothermal Sn-W ores: Insights from in situ analyses of fluid inclusions by UV-fs-LA-ICP-MS. PhD thesis, University of Hannover, Germany.

Anders, E., Grevesse, N., 1989. Abundances of the elements: Meteoritic and solar. Geochimica et Cosmochimica Acta 53, 197-214.

Baumann, L., Kuschka, E., Seifert, T., 2000. Ore deposits of the Erzgebirge. Enke im ThiemeVerlag, Stuttgart, 300 p. (in German)

Benek, R., 1991. Aspects of volume calculation of paleovolcanic eruptive products- the example of the Teplice rhyolite (east Germany). Zeitschrift für Geologische Wissenschaften 19, 379-389.

Beurlen, H., Müller, A., Silva, D., Da Silva, M.R.R., 2011. Petrogenetic significance of traceelement data analyzed with LA-ICP-MS in quartz from the Borborema pegmatite province, northeastern Brazil. Mineralogical Magazine 75, 2703-2719.

Beus, A.A., Severov, E.A., Sitnin, A.A., Subbotin, K.D., 1962. Albitized and Greisenized Granites (Apogranites), Moscow, Nauka, 196 p.(in Russian)

Bolduan. H., Lächelt, A., Malásek, F., 1967. Geology and Mineralization of the Zinnwald (Cínovec) deposit. Freiberger Forschungshefte C 218, 35-52. (in German)

Breiter, K., 1997. The Teplice rhyolite (Krušné Hory Mts., Czech Republic) - chemical evidence of a multiply exhausted stratified magma chamber. Věstník Českého Geologického Ústavu $72,205-213$. 
Breiter, K., Müller, A., 2009. Evolution of rare metal-specialised granite melt documented by quartz chemistry. European Journal of Mineralogy 21, 335-346. Breiter, K., Förster, H.-J., Seltmann, R., 1999. Variscan silicic magmatism and related tin-tungsten mineralization in the Erzgebirge-Slavkovský les metallogenic province. Mineralium Deposita 34, 505-531.

Breiter, K., Novák, J.K., Chulpáčová, M., 2001. Chemical evolution of volcanic rocks in the Altenberg-Teplice Caldera (Eastern Krušné Hory Mts., Czech Republic, Germany). Geolines 13, 17-22.

Breiter, K., Müller, A., Leichmann, J., Gabašová, A., 2005. Textural and chemical evolution of a fractionated granitic system: the Podlesí stock, Czech Republic. Lithos 80, 323-345.

Breiter, K., Svojtka, M., Ackerman L., Švecová K., 2012. Trace element composition of quartz from the Variscan Altenberg-Teplice caldera (Krušné hory/Erzgebirge Mts, Czech Republic/Germany): Insights into the volcano-plutonic complex evolution. Chemical Geology 326-327, 36-50.

Breiter, K., Ďurišová, J., Dosbaba, M., 2017. Quartz chemistry - a step to understanding magmatic-hydrothermal processes in ore-bearing granites: Cínovec/Zinnwald Sn-W-Li deposit, Central Europe. Ore Geology Reviews 90, 25-35.

Breitkreuz, C., Renno, A., Schneider, J.-W., Stanek, K., 2009. Late Paleozoic volcanosedimentary evolution of the Elbe Zone and the eastern Erzgebirge. Exkursionsführer und Veröffentlichungen der DGG, Hannover, 241, 219-230.

Čada, M., Novák, J. K., 1974. Spatial distribution of greisen types at the Cínovec-South tin deposit, in: Štemprok, M. (ed.), Metallization Associated with Acid Magmatism, vol. 1. Czech Geological Survey, Prague, pp. 383-388.

Cocherie, A., Johan, V., Rossi, P., Štemprok, M., 1991. Trace element variations and lanthanide tetrad effect studied in a Variscan lithium albite granite: Case of the Cínovec granite (Czechoslovakia), in: Pagel, M., Leroy, J.-L. (eds.), Source, transport and deposition of Metals. Balkema, Rotterdam, pp. 745-749.

Dahm, K. P., Thomas, R., 1985. A new genetic model of tin deposits of the Erzgebirge (quartzcassiterite formation). Freiberger Forschungshefte C 390, 254-274. (in German)

Dennen, W.H., 1966. Stoichiometric substitution in natural quartz. Geochimica et Cosmochimica Acta $30,1235-1241$. 
Dolejš, D., Štemprok, M., 2001. Magmatic and hydrothermal evolution of Li-F granites: Cinovec and Krásno intrusions, Krušné hory batholith, Czech Republic. Bulletin of the Czech Geological Survey 76, 77-99.

Donovan, J.J., Lowers, H.A., Rusk, B.G., 2011. Improved electron probe microanalysis of trace elements in quartz. American Mineralogist 96, 274-282.

Ďurišová, J., Charoy, B., Weisbrod, A., 1979. Fluid inclusion studies in minerals from tin and tungsten deposits in the Krušné Hory Mountains (Czechoslovakia). Bulletin de Minéralogie 102, 665-675.European Metals Holdings Limited, 2017. Cínovec Maiden ore reserve - further information. $<$ https://www.europeanmet.com/wpcontent/uploads/2017/07/20170704-EMH-Ore-Reserve-Further-Information-July-42017.pdf $>$ Accessed August 282017.

Flem, B., Larsen, R.B., Grimstvedt, A., Mansfeld, J., 2002. In situ analysis of trace elements in quartz by using laser ablation inductively coupled plasma mass spectrometry. Chemical Geology 182, 237-247.

Förster, H.-J., 1998. The Variscan granites of the Erzgebirge and their accessory minerals. Habilitation thesis, Technical University Bergakademie Freiberg, 270 p. . (in German)

Förster, H.-J., Seltmann, R., Tischendorf, G., 1995. High-fluorine, low phosphorus A-type (postcollision) silicic magmatism in the Erzgebirge. $2^{\text {nd }}$ Symposium of Permocarboniferous Igneous Rocks, Bonn, Terra Nostra. 7, 32- 35.

Förster, H.-J., Tischendorf, G., Seltmann, R., Gottesmann, B., 1998. Die variszischen Granite des Erzgebirges: neue Aspekte aus stofflicher Sicht. Zeitschrift für Geologische Wissenschaften 26, 31-60.

Förster, H.-J., Tischendorf, G., Trumbull, R.B., Gottesmann, B., 1999. Late-collisional granites in the Variscan Erzgebirge, Germany. Journal of Petrology 40, 1613-1645. Garate-Olave, I., Müller, A., Roda-Robles, E., Gil-Crespo, P.P., Pesquera, A., 2017. Extreme fractionation in a granite-pegmatite system documented by quartz chemistry: The case study of Tres Arroyos (Central Iberian Zone, Spain). Lithos 286-287, 162-174.

Götte, T., 2016. Trace element composition of authigenic quartz in sandstones and its correlation with fluid- rock interaction during diagenesis. In: Armitage, P. J., Butcher, A. R., Churchill, J. M., Csoma, A. E., Hollis, C., Lander, R. H., Omma, J. E., Worden, R. H. (eds.) 
Reservoir Quality of Clastic and Carbonate Rocks: Analysis, Modelling and Prediction. Geological Society of London Special Publications 435.

Götze, J., Plötze, M., Habermann, D., 2001. Origin, spectral characteristics and practical applications of the cathodoluminescence (CL) of quartz - a review. Mineralogy and Petrology 71, 225-250.

Götze, J., Plötze, M., Graupner, T., Hallbauer, D.K., Bray, C.J., 2004. Trace element incorporation into quartz: a combined study by ICP-MS, electron spin resonance, cathodoluminescence, capillary ion analysis, and gas chromatography. Geochimica et Cosmochimica Acta 68, 3741-3759.

Graupner, T., Brätz, H., Klemd, R., 2005, LA-ICP-MS micro-analysis of fluid inclusions in quartz using a commercial Merchantek $266 \mathrm{~nm} \mathrm{Nd:YAG} \mathrm{laser.} \mathrm{European} \mathrm{Journal} \mathrm{of}$ Mineralogy 17, 93-102.

Gurbanov, A.G., Chernukha, D.G., Koshchug, D.G., Kurasova, S.P., Fedyushchenko, S.V., 1999. EPR spectroscopy and geochemistry of rock-forming quartz as an indicator of the superimposed processes in rocks of igneous associations of various ages in the Greater Caucasus. Geochemistry International 37, 519-604.

Harben, P.W., 2002. The Industrial Mineral Handybook - a Guide to Markets, Specifications and Prices, 4th edition. Industrial Mineral Information, Surrey, $412 \mathrm{p}$.

Hoffmann, U., Breitkreuz, C., Breiter, K., Sergeev, S., Stanek, K., Tichomirowa, M., 2013. Carboniferous-Permian volcanic evolution in Central Europe - U/Pb ages of volcanic rocks in Saxony (Germany) and northern Bohemia (Czech Republic). International Journal of Earth Sciences 102, 73-99.

Hoth, K., Berger, H.-J., Breiter, K., Mlčoch, B., Schovánek, P., 1995. Geological map of the Erzgebirge/Vogtland 1:100 000. Sächsisches Landesamt für Umwelt und Geologie, Freiberg. (in German)

Huang, R., Audétat, A., 2012. The titanium-in-quartz (TitaniQ) thermobarometer: A critical examination and re-calibration. Geochimica et Cosmochimica Acta 84, 75-89.

Jacamon, F., Larsen, R.B., 2009. Trace element evolution of quartz in the charnockitic Kleivan granite, SW-Norway: the Ge/Ti ratio of quartz as an index of igneous differentiation. Lithos 107, 281-291. 
Jiránek, J., Kř́́bek, B., Mlčoch, B., Procházka, J., Schovánek, P., Schovánková, D., Schulmann, K., Šebesta, J., Šimůnek, Z., Štemprok, M., 1987. The Teplice rhyolite. Report Czech Geological Survey, Praha, 114 p. (in Czech).

Jochum, K.P., Weis, U., Stoll, B., Kuzmin, D., Yang, Q., Raczek, I., Jacob, D.E., Stracke, A., Birbaum, K., Frick, D.A., Günther, D., Enzweiler, J., 2011. Determination of reference values for NIST SRM 610-617 glasses following ISO guidelines. Geostandards and Geoanalytical Research 35, 397-429.

Johan, V., Johan, Z., 1994. Accessory minerals of the Cínovec (Zinnwald) granite cupola, Czech Republic, Part 1: Nb-, Ta-, and Ti-bearing oxides. Mineralogy and Petrology 49, 1-21.

Johan, V., Johan, Z., 2005. Accessory minerals of the Cínovec (Zinnwald) granite cupola, Czech Republic: Indicators of petrogenetic evolution. Mineralogy and Petrology 83, 113-150.

Johan, Z., Strnad, L. Johan, V., 2012. Evolution of the Cínovec (Zinnwald) granite cupola, Czech Republic: Composition of feldspars and micas, a clue to the origin of W, Sn mineralization. Canadian Mineralogist 50, 1131-1148.

Jourdan, A.-L., Vennemann, T.W., Mullis, J., Ramseyer, K., Spiers C.J., 2009. Evidence of growth and sector zoning in hydrothermal quartz from Alpine veins. European Journal of Mineralogy 21, 219-231.

Landtwing, M. R., Pettke, T., 2005. Relationships between SEM-cathodoluminescence response and trace-element composition of hydrothermal vein quartz. American Mineralogist 90, 122-131.

Larsen, E., Kleiv, R.A., 2016. Flotation of quartz from quartz-feldspar mixtures by the HF method. Minerals Engineering 98, 49-51.

Larsen, E., Kleiv, R.A., 2015. Towards a new process for the flotation of quartz. Minerals Engineering 83.13-18.

Larsen, R.B., Polvè, M., Juve, G., 2000. Granite pegmatite quartz from Evje-Iveland: Trace element chemistry and implications for the formation of high-purity quartz. Norges Geologiske Undersøkelse Bulletin 436, 57-65.

Larsen, R.B., Henderson, I., Ihlen, P.M., 2004. Distribution and petrogenetic behaviour of trace elements in granitic pegmatite quartz from South Norway. Contributions to Mineralogy and Petrology 147, 615-628. 
Lester, G. W., Kyser, T. K., Clark, A. H., Layton-Mathews, D., 2013. Trace element partitioning between immiscible silicate melts with $\mathrm{H}_{2} \mathrm{O}, \mathrm{P}, \mathrm{S}, \mathrm{F}$, and Cl. Chemical Geology 357, 178185.

Lyakhovich, V.V., 1972. Trace Elements in Rock-Forming Minerals of Granitoids, Nedra, Moscow, 200 p. (in Russian).

Martin, J., Armington, A. 1983. Effect of growth rate on quartz defects. Journal of Crystal Growth 62, 203-206.

Mlčoch, B., 1994. The geological structure of the crystalline basement below the North Bohemian brown coal basin, in: Hirschmann, G., Harms, U. (eds.), KTB Report 93/4. Niedersächsisches Landesamt für Bodenforschung. Hannover, pp. 39-46.

Monecke, T., Kempe, U., Götze, J., 2002. Genetic significance of the trace element content in metamorphic and hydrothermal quartz: a reconnaissance study. Earth and Planetary Science Letters 202, 709-724.

Müller, A., Koch-Müller, M., 2009. Hydrogen speciation and trace element contents of igneous, hydrothermal and metamorphic quartz from Norway. Mineralogical Magazine 73, 569-583.

Müller, A., Seltmann, R., 1999. The genetic significance of snowball quartz in high fractionated tin granites of the Krušné Hory/Erzgebirge, in: Stanley, C. et al. (eds.), Mineral Deposits: Processes to Processing. Proceedings of the 5th Biennial SGA Meeting London, Volume 1, Balkema, Rotterdam, pp. 409-412.

Müller, A., Seltmann, R., 2002. Plagioclase-mantled K-feldspar in the Carboniferous porphyritic microgranite of Altenberg-Frauenstein, Eastern Erzgebirge/Krušné Hory. Bulletin of the Geological Society of Finland 74, 53- 79.

Müller, A., Seltmann, R., Behr, H.-J., 2000. Application of cathodoluminescence to magmatic quartz in a tin granite - case study from the Schellerhau Granite Complex: Mineralium Deposita 25, 169-189.

Müller, A., Kronz, A., Breiter, K., 2002. Trace elements and growth patterns in quartz: a fingerprint of the evolution of the subvolcanic Podlesí Granite System (Krušné Hory, Czech Republic). Bulletin of the Czech Geological Survey 77, 135-145.

Müller, A., Wiedenbeck, M., van den Kerkhof, A.M., Kronz, A., Simon, K., 2003. Trace elements in quartz - a combined electronmicroprobe, secondary ion mass spectrometry, 
laser-ablation ICP-MS, and cathodoluminescence study. European Journal of Mineralogy $15,747-763$.

Müller, A., Breiter, K., Seltmann, R., Pécskay, Z., 2005. Quartz and feldspar zoning in the eastern Erzgebirge volcano-plutonic complex (Germany, Czech Republic): evidence of multiple magma mixing. Lithos 80, 201-227.

Müller, A., Wiedenbeck, M., Flem, B., Schiellerup, H., 2008. Refinement of phosphorus determination in quartz by LA-ICP-MS through defining new reference material values: Geostandards and Geoanalytical Research 32, 361-376.

Müller, A., van den Kerkhof, A.M., Behr, H.-J., Kronz, A., Koch-Müller, M., 2010a. The evolution of late-Hercynian granites and rhyolites documented by quartz-a review: Geological Society of America Special Paper 472, 185-204.

Müller, A., Herrington, R., Armstrong, R., Seltmann, R., Kirwin, D.J., Stenina, N.G., Kronz, A., 2010b. Trace elements and cathodoluminescence of quartz in stockwork veins of Mongolian porphyry-style deposits. Mineralium Deposita 45, 707-727.

Müller, A., Wanvik, J. E., Ihlen, P.M., 2012. Petrological and chemical characterisation of highpurity quartz deposits with examples from Norway, in: Götze J., Möckel R. (eds.), Quartz: Deposits, Mineralogy and Analytics, Springer, Berlin, pp. 71-118.

Neßler, J., Seifert, T., Gutzmer, J., Müller, A., Stute, S., Kühn, K., 2013. Geology and Exploration of the Li-Sn-W-Rb-Cs-deposit Zinnwald, eastern Erzgebirge, Germany, in: Jonsson, E. et al. (eds.), Mineral deposit research for a high-tech world. Proceedings of the 12th Biennial SGA Meeting, Uppsala, Sweden, pp. 1734-1737.

Neßler, J., Seifert, T., Gutzmer, J., 2015. New Sn-W Potential at the Zinnwald/Cínovec Deposit, Eastern Erzgebirge, Germany, in: André-Meyer, A.-S. et al. (Eds.), Mineral resources in a sustainable world. Proceedings of the 13th SGA Biennial Meeting, Nancy,Vol. 2, pp. 819822.

O’Brien, P.J., Carswell, D.A., 1993. Tectonometamorphic evolution of the Bohemian Massif: evidence from high-pressure metamorphic rocks. Geologische Rundschau 82, 531-555.

Perny, B., Eberhardt, P., Ramseyer, K., Mullis, J., Pankrath, R., 1992. Microdistribution of Al, Li, and $\mathrm{Na}$ in $\alpha$ quartz: Possible causes and correlation with short-lived cathodoluminescence. American Mineralogist 77, 534-544. 
Pokrovskii, G.S., Schott, J., 1998. Thermodynamic properties of aqueous Ge(IV) hydroxide complexes from 25 to $350^{\circ} \mathrm{C}$ : Implications for the behavior of germanium and the $\mathrm{Ge} / \mathrm{Si}$ ratio in hydrothermal fluids. Geochimica et Cosmochimica Acta 62, 1631-1642.

Pokrovskii, V.A., Helgeson, H.C., 1995. Thermodynamic properties of aqueous species and the solubilities of minerals at high pressures and temperatures: the system $\mathrm{Al}_{2} \mathrm{O}_{3}-\mathrm{H}_{2} \mathrm{O}-\mathrm{NaCl}$. American Journal of Science 295, 1255-1342.

Romer, R.L., Thomas, R., Stein, H.J., Rhede, D., 2007. Dating multiply overprinted Snmineralized granites - examples from the Erzgebirge, Germany. Mineralium Deposita 42, 337-359.

Romer, R.L., Förster, H.-J., Štemprok, M. (2010) Age constraints for the late-Variscan magmatism in the Altenberg-Teplice Caldera (Eastern Erzgebirge/Krušné hory). Neues Jahrbuch für Mineralogie, Abhandlungen187, 289-305.

Rötzler, K., Plessen, B., 2010. The Erzgebirge: a pile of ultrahigh- to low-pressure nappes of early Palaeozoic rocks, in: Linnemann, U., Kroner, U., Romer, R.L. (eds.), From the Cadomian Active Margin to the Variscan Orogen: The pre-Mesozoic Geology of SaxoThuringia (NE Bohemian Massif). Schweizerbart, Stuttgart, pp. 253-270.

Rötzler, K., Schumacher, R., Maresch, W.V., Willner, A.P., 1998. Characterization and geodynamic implications of contrasting metamorphic evolution in juxtaposed highpressure units of the Western Erzgebirge (Saxony, Germany). European Journal of Mineralogy 10, 261-280.

Rub, M. G., Pavlov, V. A., Rub, A. K. Štemprok, M., Drábek, M., Drábková, E., 1983. Elements of vertical zoning in the Cinovec massif of lithium fluorine granites (Czechoslovakia), in: Bogatikov, O.A., Borsuk, A.M. (eds.) Correlation of magmatic rocks of Czechoslovakia and some districts of the USSR. Nauka, Moskva, pp. 108-137. (in Russian).

Rub, A. K., Štemprok, M., Rub, M. G., 1998. Tantalum mineralization in the apical part of the Cínovec (Zinnwald) granite stock. Mineralogy and Petrology 63, 199-222.

Rudnick, R.L., Gao, S., 2004. Composition of the continental crust, in: Holland, H.D., Turekian, K.K. (eds.), Treatise on Geochemistry. Vol. 3. Elsevier, Amsterdam, pp. 1-65.

Rusk, B., 2012. Cathodoluminescent textures and trace elements in hydrothermal quartz, in: Götze, J., Möckel, R. (Eds.), Quartz: Deposits, Mineralogy and Analytics. Springer, Heidelberg, New York. pp. 307-329. 
Rusk, B.G., Lowers, H.A., Reed, M.H., 2008. Trace elements in hydrothermal quartz: relationships to cathodoluminescence textures and insights into vein formation. Geology 36, $547-550$.

Salvi, S., Pokrovski, G.S., Schott, J., 1998. Experimental investigation of aluminum-silica aqueous complexing at $300^{\circ} \mathrm{C}$. Chemical Geology 151, 51-67.

Schrön, W., Schmädicke, E., Thomas, R., Schmidt, W., 1988. Geochemical investigations of pegmatite quartz. Zeitschrift der Geologischen Wissenschaften 16, 229-244. (in German).

Seifert, T., Pavlova, G.G., 2016. New ${ }^{40} \mathrm{Ar} /{ }^{39} \mathrm{Ar}$ ages of Sn- and W-polymetallic mineralization in the Erzgebirge/Krušné hory (DE, CZ). Goldschmidt Conference Abstracts, Yokohama 26 June - 1 July 2016, p. 2792.

Seifert, T., Atanasova, P., Gutzmer, J., Pfände, J., 2011. Mineralogy, geochemistry and age of greisen mineralization in the Li-Rb-Cs-Sn-W deposit Zinnwald, Erzgebirge, Germany. Mineralogical Magazine 75, 1833.

Seltmann, R., Breiter, K., Schilka, W., Benek, R., 1996. The Altenberg-Teplice caldera: reversed zonation of a stratified magma chamber. Journal of Conference Abstracts 1, 556.

Seltmann, R., Förster, H.-J., Gottesmann, B., Sala, M., Wolf, D., Štemprok, M., 1998. The Zinnwald greisen deposit related to post-collisional A-type silicic magmatism in the Variscan Eastern Erzgebirge/Krušné Hory, in: Breiter, K. (ed.), Genetic Significance of Phosphorus in Fractionated Granites. Excursion guide. Geological Survey, Prague, pp. 3350 .

SolarWorld Solicium GmbH (2014) Zinnwald Lithium Project. Report According to PERC Standard. $<$ http://www.be-part-of-avision.com/fileadmin/downloads_new/konzern/nachhaltigkeit/sw_zinnwald_perc-report1.pdf> Accessed 12 February 2018.

Štemprok, M., 1960. On the genesis of the ore deposit of Cínovec (Zinnwald). International Geological Congress, Session 21, Report, Copenhagen, p. 43-52.

Štemprok, M., 1961. Genetic investigations of flat-dipping veins of the Cínovec (Zinnwald) deposit in the Erzgebirge. Sborník Ústředního Ústavu Geologického26, 455-527. (in German).

Štemprok, M., 1965. Petrography and the vertical extension of the mineralization of the Cínovec granite massif. Sborník Geologických věd, Řada Ložisková Geologie 5, 7-106 (in Czech) 
Štemprok, M., 1989. Rare earth elements in the rocks of the Cínovec cupola (Czechoslovakia). Bulletin of the Geological Survey, Prague 64, 1-16.

Štemprok, M., Šulcek. Z., 1969. Geochemical profile through an ore-bearing lithium granite. Economic Geology 64, 392-404.

Štemprok, M., Seltmann, R., Breiter, K., 1995. The Cínovec/Zinnwald Sn-W-Li deposit, in: Breiter, K., Seltmann, R. (eds.), Excursion guide: Ore mineralizations of the Krušné Hory Mts. (Erzgebirge), $3^{\text {rd }}$ SGA Meeting, Prague, Czech Republic, Czech Geological Survey, pp. $77-83$.

Štemprok, M., Holub, F.V., Novák, J.K., 2003. Multiple magmatic pulses of the Eastern Erzgebirge Volcano-Plutonic Complex, Krušné hory/Erzgebirge batholith, and their phosphorus contents. Bulletin of Geosciences 78, 277-296.

Sushchevskaya, T. M., Ďurišová, J., Yerokhin, A. M., Knyazeva, S. N., Kokina, T. A., Kalinichenko, A. M., Lokhov, K. I., Prisyagina, N. I., 1996. A study of the chemical characteristics of the medium of cassiterite-quartz-type tin mineralization based on the fluid inclusions in minerals. Geochemistry International 33, 1-22.

Suttner, L., Leininger, R.K., 1972. Comparison of the trace element content of plutonic, volcanic and metamorphic quartz from Southwestern Montana. Geological Society of America Bulletin 83, 1855-1862.

Tichomirowa, M., 1997. ${ }^{207} \mathrm{~Pb} /{ }^{206} \mathrm{~Pb}$-single-zircon datingof the emplacement age of theNiederbobritzsch granite. Terra Nostra 8, 183-184. (in German)

Thomas, R., 1994. Fluid evolution in relation to the emplacement of the Variscan granites in the Erzgebirge region: a review of the melt and fluid inclusion evidence, in: Seltmann, R., Kämpf, H., Möller, P. (eds.), Metallogeny of Collisional Orogens. Czech Geological Survey, Prague, pp. 70-81.

Thomas, R., Förster, H.-J., Rickers, K. and Webster, J. D., 2005. Formation of extremely F-rich hydrous melt fractions and hydrothermal fluids during differentiation of highly evolved tingranite magmas: A melt/fluid-inclusion study. Contributions to Mineralogy and Petrology $148,582-601$.

Wardell Armstrong International (2015) Competent person's report on the CINOVEC lithium-tin project, Czech Republic. November 2015, Truro, United Kingdom.

$<$ https://www.europeanmet.com/wp- 
content/uploads/2017/03/CPR_2015_FinalV2_Signed_copy_2.pdf $>$ Accessed $3^{\text {rd }}$ July 2017.

Wark, D.A., Watson, E.B., 2006. TitaniQ: a titanium-in-quartz geothermometer. Contributions Mineralogy and Petrology 152, 743-754. DOI:10.1007/s00410-006-0132-1.

Watt, G.R., Wright, P., Galloway, S., McLean, C., 1997. Cathodoluminescence and trace element zoning in quartz phenocrysts and xenocrysts. Geochimica et Cosmochimica Acta 61, 4337-4348.

Webster, J., Thomas, R., Förster, H.-J., Seltmann, R., Tappen, C., 2004. Geochemical evolution of halogen-enriched granite magmas and mineralizing fluids of the Zinnwald tin-tungsten mining district, Erzgebirge, Germany. Mineralium Deposita 39, 452-472.

Willner, A.P., Rötzler, K., Maresch, V.W., 1997. Pressure-temperature and fluid evolution of quartzo-feldspathic metamorphic rocks with a relic high-pressure, granulite-facies history from the Central Erxgebirge (Saxony, Germany). Journal of Petrology 38, 307-336. 


\section{Tables}

Table 1. Lithium, Sn and W resource estimations for the German and Czech part of the Zinnwald/Cínovec deposit.

Table 2. Whole rock analyses of rocks from the Tiefer Bünaustolln adit.

Greisen - massive quartz-zinnwaldite greisen, TR3 - Teplice rhyolite phase 3, ZiG - Zinnwald albite granite. $\mathrm{Fe}_{2} \mathrm{O}_{3}$ is given as the total of ferrous and ferric oxide value.

Table 3. Average compositions of quartz in various rock types determined by LA-ICP-MS.

LOD - limit of detection, $\mathrm{n}$ - number of analyses, STD - Standard deviation, ZiG - Zinnwald albite granite. 


\section{Supplementary Material}

Table SM1. List and location of individual samples.

Coordinates are given as UTM Zone U33 and as Gauß-Krüger values. TR3 - Teplice rhyolite phase 3; ZiG - Zinnwald albite granite. The altitude is given in meters above sea level.

Table SM2. Trace element concentrations in quartz from different rock types exposed in the Tiefer Bünaustolln adit.

TR3 - Teplice rhyolite phase 3; ZiG - Zinnwald albite granite; LOD - Limit of detection. 


\section{Figure captions}

Figure 1. Simplified geological map showing the igneous units of the eastern Erzgebirge volcano-plutonic complex with the Altenberg-Teplice caldera (framed by the AltenbergFrauenstein microgranite) as the major magmatic structure. Modified from Hoth et al. (1995) and Mlčoch (1994). The black square in the Zinnwald-Georgenfeld-Cínovec area indicates the location of the map shown in Figure 2.

Figure 2. A - Geological map of the Zinnwald-Georgenfeld-Cínovec area. Modified from Baumann et al. (2000). X-Y marks the location of the cross section shown in (B). B - E-W cross section through the northern German part of the Zinnwald granite cupola.

Figure 3. Map of the Tiefer Bünaustolln with sampling sites. Sample 5.0 which was taken at the 767-m level is not indicated in the map. Coordinates are given as Gau $\beta$-Krüger values.

Figure 4. A - Massive quartz-zinnwaldite (qtz-zwd) greisen (dark violet) hosted by the Zinnwald albite granite (ZiG). B - Typical flat, 25-cm thick quartz-zinnwaldite vein (Flöz) hosted by massive quartz-zinnwaldite greisen. C - Flat vein (Flöz 12; sample 4.6) with visible wolframite (wf) and cassiterite (cst). The thickness of the flat vein in the center of the image is about $60 \mathrm{~cm}$. D - Zinnwaldite-rich flat vein (yellow arrows) in massive hematitized quartz-zinnwaldite greisen. Zinnwaldite in the vein forms comb textures along the vein contacts. The vein contains several cavities where quartz crystal faces are coated with hematite (redbrown areas). Below the vein there is a leucocratic pegmatite vein (white arrows) pre-dating the formation of the hydrothermal vein. $\mathrm{E}-20-\mathrm{cm}$ wide quartz vein (Albert Morgengang) with massive wolframite mineralization (wf) along the vein contacts. With permission of the Museum of the Vereinigt Zwitterfeld zu Zinnwald visitor mine, Zinnwald-Georgenfeld. F - Stockscheider with megacrystic K-feldspar (kfs) and pegmatite quartz (pqz) crosscut by a 3-cm wide, flat quartz vein (fqz). The stockscheider is greisenized on both sides of the vein. Height of specimen $16 \mathrm{~cm}$.

Figure 5. $\mathrm{A}-\mathrm{SiO}_{2}$ versus alumina saturation index plot of rocks exposed in the Tiefe Bünaustolln adit. Large symbols are data of this study and small symbols represent published 
data from Cocherie et al. (1991), Seltmann et al. (1998), and Breiter et al. (2012). B - $\mathrm{SiO}_{2}$ versus $\mathrm{Li}_{2} \mathrm{O}$ plot. $\mathrm{C}$ - Upper continental crust(UCC)-normalized diagram of selected incompatible elements. UCC values are from Rudnick and Gao (2004). D - Chondrite-normalized rare earth element patterns applying the chondrite values of Anders and Grevesse (1989).

Figure 6. SEM-CL images of quartz. A - Quartz phenocryst in the Teplice rhyolite (sample 1.3B) with concentric growth zoning overprinted by a dense network of healed vein-like structures (black). B - Quartz phenoblast (snowball-textured quartz) in the Zinnwald albite granite with numerous inclusions of platy albite (pinkish shaded) (sample 2.6A). The phenoblast shows weakly contrasting growth zoning. C - Quartz of the stockscheider pegmatite with dendritic habitus surrounded by $\mathrm{K}$-feldspar (Kfs) and zinnwaldite. The stockscheider quartz is of branched, dendritic structure devoid of growth zoning. D - Sketch highlighting the dendritic, almost spruce-like habit and growth direction of the stockscheider quartz shown in (C).

Figure 7. SEM-CL images of quartz. A - Quartz crystal aggregate in massive quartz-zinnwaldite greisen showing fine, weakly contrasted growth zoning (sample 2.4A). B - Quartz with oscillatory growth zoning in massive quartz-zinnwaldite greisen. The type of zoning resembles those of the phenoblasts in the Zinnwald albite granite and, therefore, this type of crystal cores represent overgrown, relic (greisenized) phenoblasts (sample 2.4A). C - Coarse-grained, hydrothermal vein quartz (Flöz 7) with oscillatory growth zoning (sample 1.11). D - Cluster of the small vein quartz crystals (Flöz 7) with sericite/albite/kaolinite (white) inclusions in the crystal cores and interstices (sample 1.11). E - Tip of a euhedral smoky quartz crystal from a cavity in a flat vein (Flöz 11) with displayed laser ablation spots and concentrations of Al, Ti, Li, and Ge. Sample 5.0.

Figure 8. Trace element chemistry of quartz. TR3 - Teplice rhyolite phase 3, BtG - Zinnwald protolithionite granite, $\mathrm{ZiG}$ - Zinnwald albite granite, apfu - atoms per formula unit.

Figure 9. Trace element variability of quartz of flat veins along a $600 \mathrm{~m}$ long profile through the northern part of the Zinnwald/Cínovec Sn-W-Li deposit at the 750-m level (Tiefer Bünaustolln). The dots represent average values of three LA-ICP-MS analyses. 
Figure 10. Variability of trace element concentrations in hydrothermal quartz across one flat vein (Flöz 7). A - Photograph of the sampling site with sampling locations. B - Al versus Ti plot. C $\mathrm{Al}$ versus Li plot. $\mathrm{D}-\mathrm{Al}$ versus Ge plot. The grey shaded areas correspond to all analyses of quartz of flat veins.

Figure 11. A - Logarithmic Ti versus Al plot of quartz of the Zinnwald/Cínovec Sn-W-Li deposits compared with data from Rusk (2012) including c. 30 porphyry-type (Cu-Mo-Au) deposits, orogenic Au deposits, and epithermal deposits. For symbol explanation see Figure 8A. $\mathrm{B}$ - Logarithmic Al/Ti versus Ge/Ti plot. For explanations of symbols and shaded areas see Figure 8A. 











Table 1. Lithium, Sn and W resource estimations for the German and Czech part of the Zinnwald/Cínovec deposit.

\begin{tabular}{|l|l|l|l|l|l|}
\hline & Ore tonnage (Mt) & $\begin{array}{l}\text { Li grade } \\
(\mathrm{ppm})\end{array}$ & $\begin{array}{l}\text { Sn grade } \\
(\mathrm{ppm})\end{array}$ & $\begin{array}{l}\text { W grade } \\
(\mathrm{ppm})\end{array}$ & Reference \\
\hline $\begin{array}{l}\text { German } \\
\text { part of the } \\
\text { deposit }\end{array}$ & $\begin{array}{l}50 \\
\text { (measured+indicated+ } \\
\text { inferred resources) }\end{array}$ & 3200 & 400 & 80 & $\begin{array}{l}\text { SolarWorld } \\
\text { Solicium GmbH } \\
(2014)\end{array}$ \\
\hline $\begin{array}{l}\text { Czech part } \\
\text { of the } \\
\text { deposit }\end{array}$ & $\begin{array}{l}220 \\
\text { (inferred resources) }\end{array}$ & 2600 & 500 & 200 & $\begin{array}{l}\text { Wardell Armstrong } \\
\text { International (2015) }\end{array}$ \\
\hline
\end{tabular}


Table 2. Representative whole rock analyses of rock exposed in the Tiefer Bünaustolln. The Zinnwald albite granite samples 2.6A, 2.7 and 4.8A were affected by greisenization as indicated by low $\mathrm{Na}_{2} \mathrm{O}$ and high LOI.

\begin{tabular}{|c|c|c|c|c|c|c|c|c|}
\hline Rock & TR3 & ZiG & ZiG & ZiG & ZiG & Greisen & Greisen & Greisen \\
\hline Sample & $1.3 \mathrm{~B}$ & $2.6 \mathrm{~A}$ & 2.7 & $3.4 \mathrm{~A}$ & $4.8 \mathrm{~A}$ & $1.4 \mathrm{~A}$ & $2.4 \mathrm{~A}$ & $4.6 \mathrm{~A}$ \\
\hline \multicolumn{9}{|c|}{ Major elements (wt.\%) } \\
\hline $\mathrm{SiO}_{2}$ & 76.21 & 74.69 & 74.8 & 73.65 & 72.45 & 74.34 & 79.63 & 73.22 \\
\hline $\mathrm{TiO}_{2}$ & 0.16 & $<0.01$ & $<0.01$ & $<0.01$ & $<0.01$ & $<0.01$ & $<0.01$ & 0.01 \\
\hline $\mathrm{Al}_{2} \mathrm{O}_{3}$ & 12.19 & 13.77 & 15.1 & 14.81 & 15.98 & 15.42 & 11.07 & 15.56 \\
\hline $\mathrm{Fe}_{2} \mathrm{O}_{3}$ tot & 1.60 & 0.90 & 0.79 & 0.99 & 1.08 & 0.90 & 2.79 & 3.55 \\
\hline $\mathrm{MnO}$ & 0.01 & 0.09 & 0.08 & 0.10 & 0.13 & 0.10 & 0.26 & 0.41 \\
\hline $\mathrm{MgO}$ & 0.20 & 0.12 & 0.11 & 0.08 & 0.08 & 0.09 & $<0.01$ & $<0.01$ \\
\hline $\mathrm{CaO}$ & 0.37 & 0.66 & 0.1 & 0.37 & 0.85 & 0.34 & 0.54 & 0.32 \\
\hline $\mathrm{Li}_{2} \mathrm{O}$ & $<0.02$ & 0.19 & 0.26 & 0.22 & 0.39 & 0.15 & 0.71 & 1.03 \\
\hline $\mathrm{Na}_{2} \mathrm{O}$ & 0.75 & 1.33 & 0.09 & 3.15 & 1.60 & 0.05 & 0.04 & 0.04 \\
\hline $\mathrm{K}_{2} \mathrm{O}$ & 5.91 & 4.45 & 5.05 & 4.48 & 4.16 & 4.87 & 2.35 & 2.82 \\
\hline $\mathrm{P}_{2} \mathrm{O}_{5}$ & 0.04 & $<0.01$ & 0.01 & $<0.01$ & 0.01 & 0.01 & $<0.01$ & 0.01 \\
\hline $\mathrm{F}$ & 0.16 & 0.69 & 0.30 & 0.45 & $>1.00$ & 0.38 & $>1.00$ & $>1.00$ \\
\hline $\mathrm{O}=\mathrm{F}$ & 0.07 & 0.29 & 0.13 & 0.19 & $>0.42$ & 0.16 & $>0.42$ & 0.42 \\
\hline LOI & 2.30 & 3.20 & 3.50 & 1.80 & 3.00 & 3.40 & 2.10 & 2.30 \\
\hline Sum & 99.99 & 100.40 & 100.33 & 100.31 & 101.16 & 100.23 & 100.94 & 100.70 \\
\hline ASI & 1.4676 & 1.6779 & 2.6043 & 1.3833 & 1.8406 & 2.5813 & 3.0817 & 4.2041 \\
\hline \multicolumn{9}{|c|}{ Trace elements (ppm) } \\
\hline As & 4.7 & 1.7 & 2.7 & 18.5 & 19.1 & 30.7 & 76.9 & 16.9 \\
\hline $\mathrm{B}$ & 37 & 30 & 37 & 20 & 5 & 42 & 14 & $<3$ \\
\hline $\mathrm{Ba}$ & 351 & 296 & 318 & 101 & 173 & 211 & 42 & 172 \\
\hline $\mathrm{Be}$ & 4 & 6 & 3 & 9 & 8 & 6 & 11 & 16 \\
\hline $\mathrm{Bi}$ & 1.3 & 7.8 & 15.4 & 1.6 & 3.7 & 18.3 & 9 & 7.5 \\
\hline Co & 1.8 & 0.8 & 1.2 & 0.8 & $<0.2$ & 0.6 & 0.5 & 0.4 \\
\hline Cs & 19.6 & 40.4 & 41 & 34.6 & 43.1 & 40.2 & 74.8 & 106.4 \\
\hline
\end{tabular}




\begin{tabular}{|c|c|c|c|c|c|c|c|c|}
\hline $\mathrm{Cu}$ & 41.7 & 144.6 & 29.6 & 25.1 & 1.3 & 20.3 & 3.9 & 2.5 \\
\hline $\mathrm{Ga}$ & 19.5 & 39.3 & 42.7 & 43.3 & 43.1 & 45.8 & 29.8 & 33.8 \\
\hline $\mathrm{Hf}$ & 6.1 & 5.8 & 6.6 & 5.8 & 6.4 & 8.5 & 6.1 & 7.5 \\
\hline Mo & 0.9 & 2.1 & 0.1 & 0.1 & 43.2 & 0.9 & 0.6 & 0.3 \\
\hline $\mathrm{Nb}$ & 15.8 & 99.1 & 95.4 & 102.2 & 64.3 & 79.8 & 37.3 & 56.6 \\
\hline $\mathrm{Pb}$ & 17.4 & 8.4 & 15.9 & 10.2 & 4.5 & 27.1 & 15.5 & 2.6 \\
\hline $\mathrm{Rb}$ & 530 & 2214 & 2102 & 1992 & 2108 & 2020 & 2257 & 3163 \\
\hline Sc & 3 & 8 & 8 & 6 & 6 & 7 & 13 & 20 \\
\hline Sn & 42 & 145 & 135 & 156 & 360 & 186 & 133 & 4665 \\
\hline $\mathrm{Sr}$ & 26.3 & 7.9 & 9.3 & 15.5 & 18.4 & 14.9 & 29.2 & 10.1 \\
\hline $\mathrm{Ta}$ & 1.6 & 38.5 & 40.7 & 37.5 & 27.1 & 34.9 & 13.7 & 32.7 \\
\hline Th & 43.6 & 14.8 & 20 & 17.7 & 18.6 & 21.9 & 40.2 & 27.9 \\
\hline$U$ & 9.2 & 8.7 & 11.1 & 11.4 & 5.9 & 10.4 & 4.2 & 7.1 \\
\hline W & 36.9 & 16.3 & 19.2 & 16.7 & 12.5 & 28.5 & 77.4 & 18.7 \\
\hline $\mathrm{Zn}$ & 32 & 57 & 44 & 64 & 70 & 49 & 131 & 276 \\
\hline $\mathrm{Zr}$ & 175 & 40.2 & 41.9 & 37.4 & 43.1 & 51.2 & 45 & 44.4 \\
\hline$Y$ & 49.5 & 20.1 & 21.2 & 18.1 & 16.3 & 15.3 & 14.9 & 11.4 \\
\hline La & 55.8 & 10.8 & 14.2 & 12.9 & 13.4 & 18.2 & 12.6 & 11.1 \\
\hline $\mathrm{Ce}$ & 112 & 29.4 & 40.6 & 33 & 39.5 & 48.2 & 34.4 & 34.5 \\
\hline $\mathrm{Pr}$ & 12.55 & 3.59 & 4.58 & 3.94 & 4.44 & 5.22 & 3.91 & 3.76 \\
\hline $\mathrm{Nd}$ & 42.8 & 10.1 & 11.5 & 10.3 & 12 & 12.8 & 10.3 & 10 \\
\hline $\mathrm{Sm}$ & 9.18 & 2.92 & 3.42 & 2.67 & 3.16 & 3.19 & 2.83 & 2.34 \\
\hline $\mathrm{Eu}$ & 0.37 & $<0.02$ & $<0.02$ & $<0.02$ & $<0.02$ & $<0.02$ & $<0.02$ & $<0.02$ \\
\hline $\mathrm{Gd}$ & 8.62 & 2.59 & 2.84 & 2.23 & 2.33 & 2.32 & 1.89 & 1.6 \\
\hline $\mathrm{Tb}$ & 1.44 & 0.75 & 0.78 & 0.62 & 0.67 & 0.64 & 0.54 & 0.48 \\
\hline Dy & 8.82 & 5.44 & 5.82 & 4.52 & 4.88 & 4.59 & 4.05 & 3.47 \\
\hline $\mathrm{Ho}$ & 1.81 & 1.13 & 1.21 & 1.02 & 1.03 & 1 & 0.86 & 0.72 \\
\hline $\mathrm{Er}$ & 5.42 & 4.26 & 4.74 & 4 & 3.76 & 3.67 & 3.49 & 2.93 \\
\hline $\mathrm{Tm}$ & 0.8 & 0.94 & 1.04 & 0.87 & 0.86 & 0.83 & 0.76 & 0.67 \\
\hline
\end{tabular}




\begin{tabular}{l|r|r|r|r|r|r|r|r|}
\hline $\mathrm{Yb}$ & 5.04 & 8.39 & 8.76 & 7.65 & 7.39 & 7.37 & 6.81 & 5.9 \\
\hline $\mathrm{Lu}$ & 0.75 & 1.3 & 1.35 & 1.19 & 1.19 & 1.15 & 1.07 & 0.9 \\
\hline
\end{tabular}


Table 3. Average trace element concentration in quartz determined by LA-ICP-MS.

\begin{tabular}{|c|c|c|c|c|c|c|c|c|c|c|c|c|c|c|c|c|c|c|c|c|c|}
\hline LOD & $\mathrm{n}$ & \begin{tabular}{|l}
$\mathbf{L i}$ \\
0.1 \\
mean \\
\end{tabular} & STD & \begin{tabular}{|l} 
Be \\
0.03 \\
mean \\
\end{tabular} & STD & $\begin{array}{l}\text { B } \\
0.2 \\
\text { mean }\end{array}$ & STD & $\begin{array}{l}\text { Mn } \\
0.1 \\
\text { mean } \\
\end{array}$ & STD & $\begin{array}{l}\text { Ge } \\
0.1 \\
\text { mean } \\
\end{array}$ & STD & $\begin{array}{l}\mathbf{R b} \\
0.01 \\
\text { mean }\end{array}$ & STD & $\begin{array}{l}\mathbf{S r} \\
0.01 \\
\text { mean }\end{array}$ & STD & \begin{tabular}{|l} 
Al \\
6.1 \\
mean \\
\end{tabular} & STD & $\begin{array}{l}\mathrm{Ti} \\
0.5 \\
\text { mean }\end{array}$ & STD & $\begin{array}{l}\mathbf{F e} \\
1.0 \\
\text { mean } \\
\end{array}$ & STD \\
\hline TR3 & 3 & 25.4 & 2.3 & $<0.03$ & & 1.5 & 0.5 & 0.5 & 0.2 & 0.9 & 0.1 & 0.16 & 0.03 & 0.07 & 0.01 & 157.8 & 44.0 & 14.5 & 0.6 & 4.6 & 0.2 \\
\hline$Z i G$ & 12 & 9.6 & 7.8 & 0.34 & 0.28 & 1.0 & 0.4 & 0.4 & 0.4 & 1.5 & 0.5 & 0.35 & 0.57 & 0.07 & 0.05 & 207.4 & 132.6 & 4.1 & 1.7 & $<1.0$ & \\
\hline Stockscheider & 3 & 22.9 & 7.8 & 0.81 & 0.07 & 2.1 & 0.6 & 1.0 & 0.6 & 1.6 & 0.2 & 6.60 & 2.47 & 0.32 & 0.43 & 456.5 & 96.2 & 5.6 & 0.3 & 7.5 & 4.2 \\
\hline $\begin{array}{l}\text { Greisen } \\
\text { Flöze }\end{array}$ & 9 & 7.4 & 4.6 & 0.30 & 0.12 & 1.1 & 0.5 & 0.3 & 0.1 & 1.6 & 0.3 & 0.49 & 0.44 & 0.07 & 0.03 & 189.1 & 111.1 & 5.0 & 2.2 & $<1.0$ & \\
\hline $\begin{array}{l}\text { (with sample 1.11) } \\
\text { Flöze }\end{array}$ & 54 & 9.8 & 11.0 & 0.27 & 0.25 & 1.3 & 0.6 & 0.2 & 0.2 & 1.1 & 0.7 & 0.27 & 0.36 & 0.08 & 0.09 & 95.2 & 47.2 & 3.2 & 3.5 & $<1.0$ & \\
\hline (without sample 1.11) & 45 & 11.1 & 11.5 & 0.25 & 0.27 & 1.4 & 0.6 & 0.2 & 0.2 & 1.0 & 0.6 & 0.25 & 0.38 & 0.08 & 0.09 & 91.4 & 48.8 & 1.8 & 1.2 & $<1.0$ & \\
\hline Morgengänge & 12 & 5.3 & 2.3 & 0.17 & 0.10 & 0.9 & 0.2 & 0.1 & 0.1 & 1.4 & 0.4 & 0.16 & 0.09 & 0.15 & 0.31 & 78.6 & 30.7 & 2.1 & 1.6 & $<1.0$ & \\
\hline
\end{tabular}

LOD - limit of detection, $\mathrm{n}$ - number of analyses, STD - Standard deviation, ZiG - Zinnwald albite granite. 



\section{Supplementary Material Table SM1 to}

Müller, A., Herklotz, G., Giegling H.:

Chemistry of quartz related to the Zinnwald/Cínovec Sn-W-Li greisen-type deposit, Eastern Erzgebirge, Germany

Table SM1. Sample list. Coordinates are given as Gauß-Krüger values. The altitude is given in meters above sea level.

\begin{tabular}{|c|c|c|c|c|c|c|}
\hline $\begin{array}{l}\text { Sample } \\
\mathrm{nr}\end{array}$ & Rock type & \begin{tabular}{|l|}
$\begin{array}{l}\text { Thickness of Flözl } \\
\text { Morgengang }(\mathrm{cm})\end{array}$ \\
\end{tabular} & $\begin{array}{l}\text { Dip direction/dip angle of } \\
\text { Flöz and Morgengang }\left({ }^{\circ}\right) \\
\end{array}$ & R (Gauß-Krüger) & H (Gauß-Krüger) & Altitude \\
\hline 1.1 & minor Flöz above Flöz 1 (Flöz -2) in TR3 & 6 to 8 & $60 / 25$ & 5413115 & 5623439 & 752 \\
\hline 1.3 & minor Flöz above Flöz 1 (Flöz -1) in TR3 & 10 to 15 & $38 / 30$ & 5413069 & 5623371 & 752 \\
\hline $1.3 \mathrm{~A}$ & $\begin{array}{l}\text { stockscheider (endocontact pegmatite hosted } \\
\text { by ZiG }\end{array}$ & - & $83 / 26$ & 5413062 & 5623354 & 750 \\
\hline $1.3 \mathrm{~B}$ & TR3 & - & - & 5413072 & 5623368 & 751 \\
\hline 1.4 & minor Flöz above Flöz 1 (Flöz 0) hosted by ZiG & 8 to 12 & $0 / 25$ & 5413048 & 5623339 & 752 \\
\hline $1.4 \mathrm{~A}$ & Massive greisenized ZiG & - & - & 5413043 & 5623330 & 752 \\
\hline 1.6 & Flöz 2 hosted by ZiG & 20 to 30 & $108 / 16(?)$ & 5413057 & 5623283 & 752 \\
\hline 1.11 & Flöz 7 hosted by massive greisenized ZiG & 20 to 40 & horizontal & 5413023 & 5623169 & 752 \\
\hline 1.12 & $\begin{array}{l}\text { Daniel Morgengang hosted by massive } \\
\text { greisenized ZiG }\end{array}$ & 6 to 8 & $142 / 83$ & 5413024 & 5623136 & 752 \\
\hline 2.2 & Flöz 8 hosted by ZiG & 25 & $51 / 32$ & 5413060 & 5623112 & 752 \\
\hline 2.4 & Greiszecher Morgengang hosted by ZiG & 6 to 8 & $312 / 86$ & 5413092 & 5623059 & 753 \\
\hline $2.4 \mathrm{~A}$ & Massive quartz-zinnwaldite greisen & - & - & 5413092 & 5623058 & 752 \\
\hline 2.5 & Flöz 7 hosted by ZiG & 20 & $64 / 40$ & 5413097 & 5623027 & 753 \\
\hline $2.6 \mathrm{~A}$ & ZiG & - & - & 5413120 & 5622975 & 753 \\
\hline 2.7 & ZiG & - & - & 5413105 & 5622955 & 763 \\
\hline $3.1 \mathrm{~A}$ & Flöz 7 hosted by ZiG & 60 & $50 / 39$ & 5413090 & 5622925 & 770 \\
\hline 3.1B & Flöz 7 hosted by ZiG & 60 & $50 / 39$ & 5413090 & 5622925 & 770 \\
\hline $3.1 \mathrm{C}$ & Flöz 7 hosted by ZiG & 60 & $50 / 39$ & 5413090 & 5622925 & 770 \\
\hline 3.4 & Flöz 8 hosted by ZiG & 50 & $359 / 20$ & 5413029 & 5623017 & 758 \\
\hline $3.4 \mathrm{~A}$ & $Z i G$ & - & - & 5413029 & 5623014 & 758 \\
\hline
\end{tabular}




\begin{tabular}{|c|c|c|c|c|c|c|}
\hline $\begin{array}{ll}\text { Sample } \\
\text { nr }\end{array}$ & Rock type & $\begin{array}{l}\text { Thickness of Flözl } \\
\text { Morgengang }(\mathrm{cm})\end{array}$ & $\begin{array}{l}\text { Dip direction/dip angle of } \\
\text { Flöz and Morgengang }\left({ }^{\circ}\right)\end{array}$ & R (Gauß-Krüger) & H (Gauß-Krüger) & Altitude \\
\hline 3.7 & Flöz 9 hosted by massive greisenized ZiG & 30 & $50 / 24$ & 5412993 & 5623065 & 754 \\
\hline 4.1 & $\begin{array}{l}\text { Daniel Morgengang hosted by massive } \\
\text { greisenized ZiG }\end{array}$ & 10 to 15 & $128 / 83$ & 5412964 & 5623079 & 753 \\
\hline 4.2 & Flöz 11 hosted by massive greisenized ZiG & 15 to 20 & $18 / 19$ & 5412942 & 5623046 & 753 \\
\hline 4.6 & Flöz 12 hosted by massive greisenized ZiG & 50 to 150 & - & 5412897 & 5622926 & 750 \\
\hline $4.6 \mathrm{~A}$ & Massive quartz-zinnwaldite greisen & - & - & 5412902 & 5622933 & 747 \\
\hline 4.8 & $\begin{array}{l}\text { Neuschacht Morgengang hosted by } \\
\text { greisenized ZiG }\end{array}$ & 6 to 10 & $133 / 89$ & 5412847 & 5622896 & 752 \\
\hline $4.8 \mathrm{~A}$ & ZiG & - & - & 5412862 & 5622899 & 753 \\
\hline 5.0 & Quartz crystal from cavity in Flöz 11 & - & - & 5413078 & 5622951 & 767 \\
\hline
\end{tabular}

Flöz - historical name for flat hydrothermal veins; Morgengang - historical name for vertical hydrothermal veins; TR3 - Teplice rhyolite phase 3; $\mathrm{ZiG}$ - Zinnwald albite granite. 


\section{Supplementary Material Table SM2 to}

Müller, A., Herklotz, G., Giegling H.:

Chemistry of quartz related to the Zinnwald/Cínovec Sn-W-Li greisen-type deposit, Eastern Erzgebirge, Germany

Table SM2. Trace element concentrations in quartz from different rock types exposed in the adit Tiefer Bünaustolln transecting the northern part of the Late-Variscan Zinnwald/Cínovec Sn-W-Li greisen-type deposit in the Eastern Erzgebirge/Krušné Hory (German/Czech Republic).

Concentrations were determined by LA-ICP-MS and are given in ppm.

\begin{tabular}{|c|c|c|c|c|c|c|c|c|c|c|c|c|c|}
\hline & & Element & $\mathbf{L i}$ & $\mathrm{Be}$ & B & $\mathrm{Mn}$ & $\mathrm{Ge}$ & $\mathbf{R b}$ & $\mathrm{Sr}$ & Al & $\mathrm{Ti}$ & $\mathrm{Fe}$ & $\mathrm{Ga}$ \\
\hline & & $\begin{array}{l}\text { Measured } \\
\text { isotope }\end{array}$ & $\mathrm{Li}^{7}$ & $\mathrm{Be}^{9}$ & $\mathrm{~B}^{11}$ & $\mathrm{Mn}^{55}$ & $\mathrm{Ge}^{74}$ & $\mathbf{R b}^{85}$ & $\mathrm{Sr}^{88}$ & $\mathrm{Al}^{27}$ & $\mathrm{Ti}^{47}$ & $\mathrm{Fe}^{56}$ & $\mathrm{Ga}^{69}$ \\
\hline & & LOD & 0.1 & 0.03 & 0.2 & 0.1 & 0.1 & 0.01 & 0.01 & 6.1 & 0.5 & 1.0 & 0.01 \\
\hline $\begin{array}{l}\text { sample } \\
\text { nr. }\end{array}$ & rock type & analysis nr. & & & & & & & & & & & \\
\hline \multirow[t]{3}{*}{$1.3 \mathrm{~B}$} & TR3 & 1.3B-A & 27.9 & $<0.03$ & 2.0 & 0.6 & 0.9 & 0.18 & 0.07 & 134.6 & 14.4 & 4.8 & 0.13 \\
\hline & & 1.3B-B & 24.9 & 0.07 & 1.0 & 0.3 & 1.0 & 0.12 & 0.08 & 130.3 & 14.0 & 4.8 & $<0.01$ \\
\hline & & 1.3B-C & 23.5 & $<0.03$ & 1.5 & 0.7 & 0.8 & 0.18 & 0.06 & 208.5 & 15.1 & 4.3 & $<0.01$ \\
\hline \multirow[t]{3}{*}{$2.6 \mathrm{~A}$} & $\mathrm{ZiG}$ & 2.6A-A & 10.8 & 0.27 & 1.4 & 0.2 & 1.9 & 0.40 & 0.05 & 147.8 & 6.6 & $<1.0$ & 0.05 \\
\hline & & $2.6 \mathrm{~A}-\mathrm{B}$ & 17.5 & 0.57 & 1.0 & 0.6 & 2.3 & 0.48 & 0.10 & 304.9 & 3.9 & $<1.0$ & 0.10 \\
\hline & & $2.6 \mathrm{~A}-\mathrm{C}$ & 27.2 & 1.02 & 2.0 & 1.4 & 1.7 & 2.09 & 0.05 & 387.2 & 3.1 & 1.4 & 0.07 \\
\hline \multirow[t]{3}{*}{2.7} & $\mathrm{ZiG}$ & 2.7-A & 1.7 & 0.07 & 1.0 & 0.2 & 1.0 & 0.04 & 0.07 & 59.5 & 6.4 & $<1.0$ & $<0.01$ \\
\hline & & 2.7-B & 6.4 & 0.22 & 0.7 & 0.2 & 0.7 & 0.13 & 0.06 & 130.0 & 1.9 & $<1.0$ & 0.09 \\
\hline & & $2.7-C$ & 3.7 & 0.20 & 0.7 & 0.2 & 0.7 & 0.13 & 0.22 & 107.5 & 0.8 & $<1.0$ & 0.05 \\
\hline \multirow[t]{3}{*}{$3.4 \mathrm{~A}$} & $\mathrm{ZiG}$ & 3.4A-A & 4.6 & 0.28 & 0.9 & 0.3 & 1.9 & 0.17 & 0.06 & 309.8 & 4.8 & 1.1 & 0.10 \\
\hline & & $3.4 \mathrm{~A}-\mathrm{B}$ & 6.9 & 0.16 & 1.3 & 0.2 & 1.1 & 0.05 & 0.05 & 116.8 & 4.8 & $<1.0$ & 0.00 \\
\hline & & $3.4 \mathrm{~A}-\mathrm{C}$ & 14.4 & 0.44 & 0.9 & 0.2 & 1.6 & 0.28 & 0.06 & 410.1 & 5.5 & 2.0 & 0.10 \\
\hline \multirow[t]{3}{*}{$4.8 \mathrm{~A}$} & $\mathrm{ZiG}$ & 4.8A-A & 2.0 & 0.13 & 0.8 & 0.1 & 2.2 & 0.04 & 0.05 & 82.8 & 3.8 & $<1.0$ & 0.00 \\
\hline & & 4.8A-B & 15.9 & 0.63 & 0.9 & 0.3 & 1.8 & 0.29 & 0.04 & 347.6 & 3.6 & 1.3 & 0.04 \\
\hline & & $4.8 \mathrm{~A}-\mathrm{C}$ & 3.9 & 0.13 & 0.8 & 0.3 & 1.5 & 0.09 & 0.05 & 84.2 & 4.4 & $<1.0$ & 0.07 \\
\hline $1.3 \mathrm{~A}$ & Stockscheider & 1.3A-A & 13.8 & 0.73 & 1.3 & 0.4 & 1.4 & 4.56 & 0.08 & 437.2 & 5.8 & 6.8 & 0.10 \\
\hline
\end{tabular}




\begin{tabular}{|c|c|c|c|c|c|c|c|c|c|c|c|c|c|}
\hline & & 1.3A-B & 27.3 & 0.88 & 2.4 & 1.1 & 1.6 & 5.89 & 0.82 & 371.4 & 5.6 & 3.8 & 0.10 \\
\hline & & $1.3 \mathrm{~A}-\mathrm{C}$ & 27.5 & 0.82 & 2.5 & 1.6 & 1.7 & 9.34 & 0.07 & 560.9 & 5.3 & 12.0 & 0.17 \\
\hline \multirow[t]{3}{*}{1.1} & Flöz -2 & 1.1-A & 1.8 & 0.25 & 1.5 & 0.4 & 0.0 & 0.79 & 0.06 & 45.5 & 2.0 & $<1.0$ & 0.03 \\
\hline & & $1.1-\mathrm{B}$ & 4.7 & 0.35 & 2.9 & 0.2 & 0.1 & 2.13 & 0.04 & 33.0 & 2.4 & $<1.0$ & $<0.01$ \\
\hline & & $1.1-C$ & 2.0 & 0.06 & 1.3 & 0.3 & 0.1 & 0.62 & 0.35 & 29.2 & 2.7 & $<1.0$ & 0.02 \\
\hline \multirow[t]{3}{*}{1.3} & Flöz -1 & 1.3-A & 14.0 & 0.00 & 0.5 & 0.1 & 0.8 & 0.01 & 0.07 & 69.3 & 0.6 & $<1.0$ & $<0.01$ \\
\hline & & 1.3-B & 33.1 & 0.05 & 0.7 & 0.1 & 0.9 & $<0.01$ & 0.04 & 103.2 & 0.9 & $<1.0$ & $<0.01$ \\
\hline & & $1.3-\mathrm{C}$ & 3.3 & 0.07 & 1.1 & 0.1 & 0.1 & 0.02 & 0.04 & 35.8 & 4.0 & $<1.0$ & 0.08 \\
\hline \multirow[t]{3}{*}{1.4} & Flöz 0 & $1.4-\mathrm{A}$ & 1.7 & 0.22 & 2.2 & 0.2 & 0.1 & 0.43 & 0.07 & 45.1 & 2.5 & 1.7 & 0.08 \\
\hline & & 1.4-B & 2.6 & 0.31 & 2.1 & 0.1 & 0.1 & 0.47 & 0.12 & 45.1 & 2.1 & $<1.0$ & $<0.01$ \\
\hline & & 1.4-C & 3.2 & 1.78 & 3.7 & 0.7 & 0.1 & 0.95 & 0.31 & 141.1 & 5.9 & $<1.0$ & 0.14 \\
\hline \multirow[t]{3}{*}{1.6} & Flöz 2 & 1.6-A & 3.6 & 0.17 & 2.2 & 0.2 & 0.6 & 0.19 & 0.12 & 63.6 & 1.5 & $<1.0$ & 0.06 \\
\hline & & 1.6-B & 3.4 & 0.07 & 1.4 & 0.0 & 0.3 & 0.03 & 0.06 & 76.6 & 5.2 & $<1.0$ & 0.07 \\
\hline & & $1.6-\mathrm{C}$ & 2.1 & 0.27 & 0.9 & 0.3 & 1.5 & 0.06 & 0.05 & 58.9 & 1.5 & $<1.0$ & $<0.01$ \\
\hline \multirow[t]{3}{*}{1.11} & Flöz 7 & 1.11-A & 2.1 & 0.37 & 0.4 & 0.0 & 2.0 & 0.16 & 0.05 & 82.3 & 10.2 & $<1.0$ & $<0.01$ \\
\hline & & 1.11-B & 2.5 & 0.36 & 1.2 & 0.2 & 2.2 & 0.20 & 0.08 & 112.6 & 13.1 & $<1.0$ & $<0.01$ \\
\hline & & $1.11-\mathrm{C}$ & 9.7 & 0.28 & 1.4 & 0.4 & 2.2 & 0.29 & 0.08 & 78.7 & 10.9 & $<1.0$ & 0.07 \\
\hline \multirow[t]{3}{*}{$1.11 x$} & Flöz 7 (resampled) & $1-11-C-A$ & 2.0 & 0.26 & 0.5 & 0.4 & 1.8 & 0.52 & 0.04 & 116.3 & 11.6 & $<1.0$ & $<0.01$ \\
\hline & & $1-11-C-B$ & 1.8 & 0.38 & 0.9 & 0.4 & 2.0 & 0.49 & 0.05 & 130.7 & 12.4 & $<1.0$ & 0.16 \\
\hline & & $1-11-C-C$ & 3.1 & 0.26 & 0.7 & 0.3 & 2.0 & 0.15 & 0.03 & 94.2 & 10.1 & $<1.0$ & $<0.01$ \\
\hline \multirow[t]{3}{*}{$1.11 y$} & Flöz 7 (resampled) & 1-11-D-A & 2.7 & 0.57 & 0.9 & 0.4 & 2.1 & 0.40 & 0.08 & 151.4 & 8.0 & $<1.0$ & $<0.01$ \\
\hline & & 1-11-D-B & 3.3 & 0.26 & 1.3 & 0.9 & 2.5 & 0.84 & 0.22 & 179.4 & 9.4 & 1.0 & $<0.01$ \\
\hline & & 1-11-D-C & 0.3 & 0.23 & 1.3 & 0.3 & 1.9 & 0.51 & 0.02 & 80.7 & 6.6 & $<1.0$ & $<0.01$ \\
\hline \multirow[t]{3}{*}{2.5} & Flöz 7 & $2.5-\mathrm{A}$ & 0.6 & 0.04 & 0.8 & 0.2 & 0.9 & 0.04 & 0.06 & 10.2 & 1.2 & $<1.0$ & $<0.01$ \\
\hline & & $2.5-B$ & 1.4 & $<0.03$ & 1.4 & 0.1 & 0.2 & 0.14 & 0.04 & 37.0 & 2.1 & $<1.0$ & 0.03 \\
\hline & & $2.5-\mathrm{C}$ & 1.4 & 0.06 & 1.3 & 0.2 & 1.9 & 0.05 & 0.08 & 8.2 & 1.5 & $<1.0$ & 0.03 \\
\hline \multirow[t]{3}{*}{$3.1 \mathrm{~A}$} & Flöz 7 & 3.1A-A & 20.7 & 0.42 & 1.9 & 0.7 & 1.1 & 0.76 & 0.07 & 150.5 & 4.0 & $<1.0$ & 0.13 \\
\hline & & 3.1A-B & 27.9 & 0.54 & 1.6 & 0.4 & 1.7 & 0.51 & 0.06 & 187.7 & 0.8 & $<1.0$ & 0.05 \\
\hline & & $3.1 \mathrm{~A}-\mathrm{C}$ & 9.3 & 0.21 & 0.8 & 0.2 & 0.8 & 0.18 & 0.02 & 93.0 & 2.9 & $<1.0$ & 0.05 \\
\hline
\end{tabular}




\begin{tabular}{|c|c|c|c|c|c|c|c|c|c|c|c|c|c|}
\hline $3.1 \mathrm{~B}$ & Flöz 7 & 3.1B-A & 36.1 & 0.36 & 1.8 & 0.0 & 1.3 & 0.02 & 0.05 & 136.4 & 0.9 & $<1.0$ & 0.08 \\
\hline & & 3.1B-B & 34.9 & 0.16 & 2.0 & 0.0 & 1.7 & 0.01 & 0.05 & 165.9 & 1.6 & $<1.0$ & 0.11 \\
\hline & & $3.1 \mathrm{~B}-\mathrm{C}$ & 24.1 & 0.11 & 1.7 & 0.2 & 1.0 & 0.27 & 0.07 & 148.7 & 1.6 & $<1.0$ & 0.06 \\
\hline \multirow[t]{3}{*}{$3.1 \mathrm{C}$} & Flöz 7 & 3.1C-A & 35.6 & 0.42 & 1.8 & 0.2 & 1.4 & 0.22 & 0.06 & 112.5 & 2.9 & $<1.0$ & 0.06 \\
\hline & & 3.1C-B & 0.7 & 0.14 & 0.7 & 0.2 & 0.8 & 0.05 & 0.04 & 41.5 & 2.7 & $<1.0$ & $<0.01$ \\
\hline & & $3.1 C-C$ & 1.6 & 0.24 & 1.0 & 0.2 & 0.9 & 0.11 & 0.04 & 88.1 & 2.7 & $<1.0$ & 0.06 \\
\hline \multirow[t]{3}{*}{2.2} & Flöz 8 & $2.2-\mathrm{A}$ & 9.3 & 0.41 & 1.9 & 0.1 & 1.7 & 0.11 & 0.09 & 119.3 & 0.8 & $<1.0$ & 0.06 \\
\hline & & $2.2-B$ & 0.4 & 0.13 & 1.3 & 0.1 & 1.7 & 0.03 & 0.05 & 107.6 & $<0.5$ & $<1.0$ & 0.06 \\
\hline & & $2.2-\mathrm{C}$ & 7.5 & 0.25 & 1.4 & 0.4 & 1.9 & 0.13 & 0.54 & 154.0 & 1.1 & $<1.0$ & 0.09 \\
\hline \multirow[t]{3}{*}{3.4} & Flöz 8 & 3.4-A & 36.1 & 0.32 & 2.2 & 0.1 & 2.4 & 0.01 & 0.05 & 172.3 & 2.8 & $<1.0$ & 0.12 \\
\hline & & 3.4-B & 32.2 & 0.28 & 2.2 & 0.1 & 2.2 & 0.18 & 0.05 & 132.7 & 2.7 & $<1.0$ & 0.05 \\
\hline & & $3.4-C$ & 23.5 & 0.43 & 1.9 & 0.1 & 2.0 & 0.05 & 0.03 & 186.2 & 2.2 & $<1.0$ & 0.08 \\
\hline \multirow[t]{3}{*}{3.7} & Flöz 9 & 3.7-A & 1.0 & 0.43 & 1.4 & 0.3 & 0.6 & 0.07 & 0.08 & 63.2 & 0.9 & $<1.0$ & 0.07 \\
\hline & & 3.7-B & 9.8 & 0.13 & 1.0 & 0.1 & 0.7 & 0.25 & 0.07 & 74.5 & 1.4 & $<1.0$ & 0.08 \\
\hline & & $3.7-C$ & 4.0 & 0.11 & 1.0 & 0.1 & 0.7 & 0.02 & 0.06 & 28.1 & 0.7 & $<1.0$ & $<0.01$ \\
\hline \multirow[t]{3}{*}{4.2} & Flöz 11 & $4.2-\mathrm{A}$ & 4.2 & 0.19 & 1.0 & 0.1 & 0.8 & 0.04 & 0.06 & 55.9 & 1.0 & $<1.0$ & $<0.01$ \\
\hline & & $4.2-B$ & 5.3 & 0.13 & 0.7 & 0.2 & 0.9 & 0.05 & 0.05 & 52.5 & 0.4 & $<1.0$ & $<0.01$ \\
\hline & & $4.2-C$ & 4.7 & 0.13 & 0.7 & 0.1 & 1.1 & 0.04 & 0.07 & 30.9 & 1.2 & $<1.0$ & $<0.01$ \\
\hline \multirow[t]{6}{*}{5.0} & Flöz 11 crystal & $5-A$ & 8.6 & 0.29 & 1.2 & 0.1 & 1.3 & 0.04 & 0.06 & 136.1 & 0.6 & $<1.0$ & 0.13 \\
\hline & & $5-B$ & 10.4 & 0.29 & 1.1 & 0.3 & 0.4 & 0.20 & 0.04 & 110.5 & 2.0 & $<1.0$ & 0.06 \\
\hline & & $5-C$ & 10.9 & 0.20 & 1.1 & 0.2 & 0.5 & 0.14 & 0.05 & 104.7 & 0.8 & $<1.0$ & 0.10 \\
\hline & & $5-\mathrm{D}$ & 16.3 & 0.15 & 1.2 & 0.3 & 0.7 & 0.05 & 0.07 & 104.3 & $<0.5$ & $<1.0$ & 0.12 \\
\hline & & $5-E$ & 16.8 & 0.07 & 1.1 & 0.3 & 0.6 & 0.03 & 0.07 & 101.4 & 1.8 & $<1.0$ & 0.08 \\
\hline & & $5-\mathrm{F}$ & 12.6 & 0.12 & 1.1 & 0.2 & 0.6 & 0.26 & 0.05 & 102.9 & 1.5 & $<1.0$ & 0.17 \\
\hline \multirow[t]{3}{*}{4.6} & Flöz 12 & 4.6-A & 5.8 & 0.22 & 0.8 & 0.3 & 1.0 & 0.33 & 0.09 & 90.9 & 1.6 & $<1.0$ & $<0.01$ \\
\hline & & 4.6-B & 4.0 & 0.48 & 1.1 & 0.6 & 1.4 & 0.87 & 0.09 & 139.2 & 0.9 & $<1.0$ & 0.10 \\
\hline & & $4.6-C$ & 6.9 & 0.41 & 1.1 & 0.3 & 1.3 & 0.08 & 0.06 & 121.0 & 1.2 & $<1.0$ & 0.05 \\
\hline 1.12 & $\begin{array}{l}\text { Daniel } \\
\text { Morgengang }\end{array}$ & $1.12-\mathrm{A}$ & 5.3 & 0.00 & 0.6 & $<0.1$ & 0.9 & 0.11 & 1.15 & 51.3 & 0.7 & $<1.0$ & $<0.01$ \\
\hline
\end{tabular}




\begin{tabular}{|c|c|c|c|c|c|c|c|c|c|c|c|c|c|}
\hline & & $1.12-B$ & 1.7 & 0.13 & 0.9 & $<0.1$ & 1.5 & 0.11 & 0.04 & 84.4 & 2.8 & $<1.0$ & $<0.01$ \\
\hline & & $1.12-C$ & 9.2 & 0.30 & 1.3 & 0.1 & 1.9 & 0.22 & 0.07 & 137.3 & 1.5 & $<1.0$ & 0.05 \\
\hline \multirow[t]{3}{*}{4.1} & $\begin{array}{l}\text { Daniel } \\
\text { Morgengang }\end{array}$ & 4.1-A & 4.8 & 0.18 & 0.8 & 0.2 & 1.8 & 0.24 & 0.05 & 123.8 & 4.1 & 1.9 & 0.08 \\
\hline & & 4.1-B & 7.4 & 0.25 & 1.1 & 0.2 & 1.5 & 0.18 & 0.04 & 70.8 & 4.4 & $<1.0$ & 0.05 \\
\hline & & $4.1-C$ & 5.4 & 0.27 & 1.0 & 0.1 & 1.5 & 0.36 & 0.07 & 95.8 & 4.4 & $<1.0$ & 0.07 \\
\hline \multirow[t]{3}{*}{2.4} & Felix Morgengang & $2.4-\mathrm{A}$ & 6.6 & 0.07 & 1.0 & 0.2 & 1.0 & 0.17 & 0.06 & 68.3 & 0.8 & $<1.0$ & 0.05 \\
\hline & & $2.4-B$ & 7.2 & 0.26 & 1.1 & 0.2 & 1.0 & 0.20 & 0.05 & 74.2 & 0.9 & $<1.0$ & 0.11 \\
\hline & & $2.4-C$ & 2.5 & 0.15 & 0.8 & 0.1 & 1.0 & 0.03 & 0.05 & 30.2 & 0.7 & $<1.0$ & 0.04 \\
\hline \multirow[t]{3}{*}{4.8} & $\begin{array}{l}\text { Neuschächter } \\
\text { Morgengang }\end{array}$ & 4.8-A & 6.7 & 0.26 & 0.9 & 0.2 & 1.7 & 0.17 & 0.05 & 81.9 & 2.6 & $<1.0$ & $<0.01$ \\
\hline & & 4.8-B & 5.3 & 0.02 & 0.6 & 0.3 & 1.5 & 0.07 & 0.12 & 81.2 & 1.7 & $<1.0$ & 0.06 \\
\hline & & $4.8-\mathrm{C}$ & 2.0 & 0.10 & 0.5 & 0.2 & 1.0 & 0.08 & 0.05 & 43.4 & $<0.5$ & $<1.0$ & 0.08 \\
\hline \multirow[t]{3}{*}{$2.4 \mathrm{~A}$} & massive greisen & 2.4A-A & 8.2 & 0.46 & 1.0 & 0.4 & 1.7 & 0.33 & 0.03 & 310.0 & 6.3 & 2.3 & 0.06 \\
\hline & & $2.4 \mathrm{~A}-\mathrm{B}$ & 1.6 & 0.29 & 1.0 & 0.2 & 1.8 & 0.15 & 0.06 & 188.9 & 4.5 & $<1.0$ & 0.09 \\
\hline & & $2.4 \mathrm{~A}-\mathrm{C}$ & 4.3 & 0.49 & 1.0 & 0.4 & 1.6 & 0.24 & 0.04 & 310.1 & 5.6 & 1.4 & 0.05 \\
\hline \multirow[t]{3}{*}{$1.4 \mathrm{~A}$} & massive greisen & 1.4A-A & 14.3 & 0.31 & 1.8 & 0.4 & 1.8 & 0.83 & 0.06 & 95.6 & 6.9 & 1.2 & 0.12 \\
\hline & & 1.4A-B & 8.4 & 0.32 & 1.5 & 0.3 & 2.1 & 0.29 & 0.08 & 330.4 & 6.3 & 2.2 & 0.04 \\
\hline & & $1.4 \mathrm{~A}-\mathrm{C}$ & 7.8 & 0.20 & 1.6 & 0.4 & 1.6 & 0.31 & 0.14 & 90.7 & 6.0 & $<1.0$ & $<0.01$ \\
\hline \multirow[t]{3}{*}{$4.6 \mathrm{~A}$} & massive greisen & 4.6A-A & 1.3 & 0.10 & 0.5 & 0.1 & 1.3 & 0.06 & 0.06 & 45.3 & $<0.5$ & $<1.0$ & $<0.01$ \\
\hline & & 4.6A-B & 7.6 & 0.30 & 0.9 & 0.5 & 1.2 & 1.44 & 0.10 & 233.2 & 3.3 & 1.3 & 0.10 \\
\hline & & $4.6 \mathrm{~A}-\mathrm{C}$ & 13.3 & 0.28 & 0.6 & 0.3 & 1.6 & 0.76 & 0.06 & 97.4 & 5.9 & $<1.0$ & 0.04 \\
\hline
\end{tabular}

Flöz - historical name for flat hydrothermal veins; Morgengang - historical name for vertical hydrothermal veins; TR3 - Teplice rhyolite phase 3; $\mathrm{ZiG}$ - Zinnwald albite granite; LOD - Limit of detection. 